\title{
Changes in atmospheric aerosol loading retrieved from space-based measurements during the past decade
}

\author{
J. Yoon ${ }^{1, *}$, J. P. Burrows ${ }^{1}$, M. Vountas ${ }^{1}$, W. von Hoyningen-Huene ${ }^{1}$, D. Y. Chang ${ }^{2}$, A. Richter ${ }^{1}$, and A. Hilboll ${ }^{1}$ \\ ${ }^{1}$ Institute of Environmental Physics, University of Bremen, Bremen, Germany \\ ${ }^{2}$ Atmospheric Chemistry Department, Max Planck Institute for Chemistry, Mainz, Germany \\ *now at: Atmospheric Chemistry Department, Max-Planck-Institute for Chemistry, Mainz, Germany
}

Correspondence to: J. P. Burrows (burrows@iup.physik.uni-bremen.de)

Received: 17 June 2013 - Published in Atmos. Chem. Phys. Discuss.: 9 October 2013

Revised: 24 March 2014 - Accepted: 4 May 2014 - Published: 4 July 2014

\begin{abstract}
The role and potential management of short-lived atmospheric pollutants such as aerosols are currently a topic of scientific and public debates. Our limited knowledge of atmospheric aerosol and its influence on the Earth's radiation balance has a significant impact on the accuracy and error of current predictions of future climate change. In the last few years, there have been several accounts of the changes in atmospheric aerosol derived from satellite observations, but no study considering the uncertainty caused by different/limited temporal sampling of polar-orbiting satellites and cloud disturbance in the trend estimates of cloud-free aerosol optical thickness (AOT). This study presents an approach to minimize the uncertainties by use of weighted least-squares regression and multiple satellite-derived AOTs from the spaceborn instruments, MODIS (onboard Terra from 2000 to 2009 and Aqua form 2003 to 2008), MISR (Terra from 2000 to 2010), and SeaWiFS (OrbView-2 from 1998 to 2007) and thereby provides more convincing trend estimates for atmospheric aerosols during the past decade. The AOT decreases over western Europe (i.e., by up to about $-40 \%$ from 2003 to 2008). In contrast, a statistically significant increase (about $+34 \%$ in the same period) over eastern China is observed and can be attributed to the increase in both industrial output and Asian desert dust.
\end{abstract}

\section{Introduction}

Anthropogenic aerosol from both fossil fuel combustion and land use change is now well known to impact on human health and global climate change. Detailed knowledge of long-term temporal changes of local, regional, and global aerosols is needed to improve our scientific understanding of their sources and sinks, and to provide evidence as a basis for policymakers (World Meteorological Organization (WMO), 2011; World Health Organization (WHO), 2014; Solomon et al., 2007; Climate and Clean Air Coalition (CCAC), 2013; Richter et al., 2005). As a result of remarkable advances in technology over the last decades, the observations from remote sensing instrumentation on Earth-orbiting satellite platforms (e.g., Advanced Very High Resolution Radiometer (AVHRR), Total Ozone Mapping Spectrometer (TOMS), Along Track Scanning Radiometer (ATSR) Multi-angle Imaging SpectroRadiometer (MISR), Moderate Resolution Imaging Spectroradiometer (MODIS), and Seaviewing Wide Field-of-view Sensor (SeaWiFS)) now provide novel and unique information about global atmospheric aerosols (Li et al., 2009; Thomas et al., 2010; Yu et al., 2009; Zhang and Reid, 2010; Karnieli et al., 2009; Mishchenko et al., 2007; Mishchenko and Geogdzhayev, 2007; Zhao et al., 2008; Massie et al., 2004; Yoon et al., 2011; Hsu et al., 2012; de Meij et al., 2012; Xie and Xia, 2008).

AVHRR provided global aerosol observations over nearly 25 years from August 1981 to June 2005, which were used to derive global and regional trends of tropospheric aerosol (Mishchenko et al., 2007; Mishchenko and Geogdzhayev, 2007; Zhao et al., 2008, 2013). However, the results can be biased by significant problems in sensor calibration and orbital drift (Thomas et al., 2010; Yoon et al., 2011). The TOMS aerosol product over land allows for the relation between changes in atmospheric aerosol and ground sulfur dioxide emissions to be analyzed (Massie et al., 2004; Xie 
and Xia, 2008). However, the uncertainties caused by aerosol layer height and sub-pixel cloud contamination can have a serious influence on the retrieval accuracy (Herman et al., 1997; Torres et al., 1998, 2002), and therefore on trend estimates (Yoon et al., 2011). Thomas et al. (2010) investigated the global trend using ATSR-2 aerosol products from 1995 to 2001, but only covering ocean area. The global aerosol products from the instruments MODIS, MISR, and SeaWiFS have often been used for the trend estimates because of their relatively long-term observation periods, well-calibrated sensor statuses, and intensively validated data over land and ocean (Li et al., 2009; Yu et al., 2009; Zhang and Reid, 2010; Karnieli et al., 2009; Yoon et al., 2011; Hsu et al., 2012; de Meij et al., 2012). However, so far no study has discussed the unrepresentative sampling induced by limited orbital periods, different sampling times, and cloud disturbance.

The unrepresentative temporal sampling of polar-orbiting platforms can be a significant uncertainty factor for trend analysis of atmospheric aerosol, as discussed elsewhere (Li et al., 2009; Ignatov et al., 2005; Kahn et al., 2007; Levy et al., 2009; Yoon, et al., 2011, 2012; Zhao et al., 2013), and will remain partially unresolved until an adequate "fit for purpose" measurement system is established. The issue arises because of the different sampling times (e.g., local equatorial crossing times are 10:30 for Terra, 12:20 for OrbView-2, and 13:30 for Aqua), limited orbital period (i.e., roughly $100 \mathrm{~min}$ for each orbit), and frequent cloud disturbance (i.e., no retrieval of cloud-free aerosol optical thickness (AOT) due to cloud occurrence).

In this study, we used relevant polar-orbiting-satellite observations, from MODIS (Terra and Aqua), MISR (Terra), and SeaWiFS (OrbView-2), to minimize the uncertainty effect from different/limited sampling in the trend estimate. The satellites were selected on the basis of their duration of the observation periods (National Aeronautics and Space Administration (NASA), MODIS Web, 2014; Jet Propulsion Laboratory - NASA, MISR Multiangle Imaging SpectroRadiometer, 2014; Goddard Space Flight Center - NASA, SeaWiFS Project, 2014), stability of the sensor calibration (Kahn et al., 2005a; Bruegge et al., 2007; Li et al., 2009; Barnes et al., 2001; Gordon, 1998; Eplee et al., 2001), and retrieval accuracy of cloud-free AOT (Kaufman et al., 1997; Remer et al., 2005, 2008; Levy et al., 2010; Kahn et al., 2005b, 2010; von Hoyningen-Huene et al., 2003, 2006, 2011; Yoon et al., 2011). More detailed information about the instrument and satellite platform characteristics, calibration status, AOT retrieval accuracy, etc. is summarized in Table 1. In addition, the weighted least-squares regression was used to estimate the trend of cloud-free AOT since it is useful to reduce the uncertainty from cloud disturbance (Yoon et al., 2012).

This paper is organized as follows: we describe the AOT data from MODIS-Terra, MODIS-Aqua, MISR-Terra, SeaWiFS-OrbView-2, and AERONET in Sect. 2. Section 3 investigates a possible uncertainty caused by limited/different sampling time in the trend estimates of cloud- free AOT from polar-orbiting satellites. The uncertainty test is performed using real-time AERONET data resampled at the limited/different times, which are related to the orbital periods for each orbit and local equatorial crossing times of the Terra, Aqua, and OrbView-2 spacecraft. In Sect. 4, we test a new trend model for considering the uncertainty from cloud disturbance and discuss the significant improvements in the trend estimates of the satellite-retrieved AOTs. We show the trend validation by comparing the satellite-derived trends with the AERONET trends in Sect. 5, and report the trend estimates for the selected regions in Sect. 6. Section 7 summarizes and presents our results and conclusions.

\section{Regions and data sets}

Figure 1 shows the global distributions of the AOT means derived using the retrieval algorithms, developed for the independent instruments MODIS (Terra) from March 2000 to December 2009, MISR (Terra) from March 2000 to December 2010, SeaWiFS (OrbView-2) from January 1998 to December 2007, and MODIS (Aqua) from January 2003 to December 2008. Ten regions are selected for more detailed investigation in Europe, the Middle/Near East, Asia, and North America, including large urban agglomerations. Recently, changes in atmospheric aerosol resulting from direct emissions by fossil fuel combustion, secondary aerosol created by photochemical transformations of trace gases, and mineral dust downwind from deserts have been reported in these regions (Streets et al., 2003; Zhao et al., 2008; Yoon et al., 2012).

\subsection{MODIS, on NASA Terra (March 2000-December 2009) and NASA Aqua (January 2013-December 2008)}

The Moderate-Resolution Imaging Spectroradiometer (MODIS) (NASA, MODIS Web, 2000) on the Terra and Aqua spacecraft has uniquely contributed to our knowledge of atmospheric aerosols over the last decade. The first MODIS instrument was mounted on NASA Terra launched on 18 December 1999. The second instrument, mounted on the NASA Aqua spacecraft, began providing global aerosols from 4 May 2002. The main objective of these instruments is to improve our understanding of global dynamics and processes occurring on land, in the oceans, and in the lower atmosphere. They achieve global coverage every one to two days. The MODIS instruments have been well calibrated ( $\sim 2 \%$ absolute and $\sim 1 \%$ precision) (Li et al., 2009) using onboard, vicarious, and lunar calibrations. They have produced global cloud-free AOT with high accuracy $( \pm 0.05 \pm 15 \%$ over land and $\pm 0.03 \pm \sim 5 \%$ over ocean) (Kaufman et al., 1997; Remer et al., 2005, 2008; Levy et al., 2010; Zhang and Reid, 2006; Shi et al., 2011; Schutgens et al., 2013; Hyer et al., 2011), which are suitable for trend 
Table 1. The characteristics of the instruments and their corresponding platforms (i.e. MODIS-Terra, MISR-Terra, SeaWIFS-OrbView-2, and MODIS-Aqua). The calibration approach/status, aerosol retrieval accuracy, research period, and data set used in this study are summarized for each instrument.

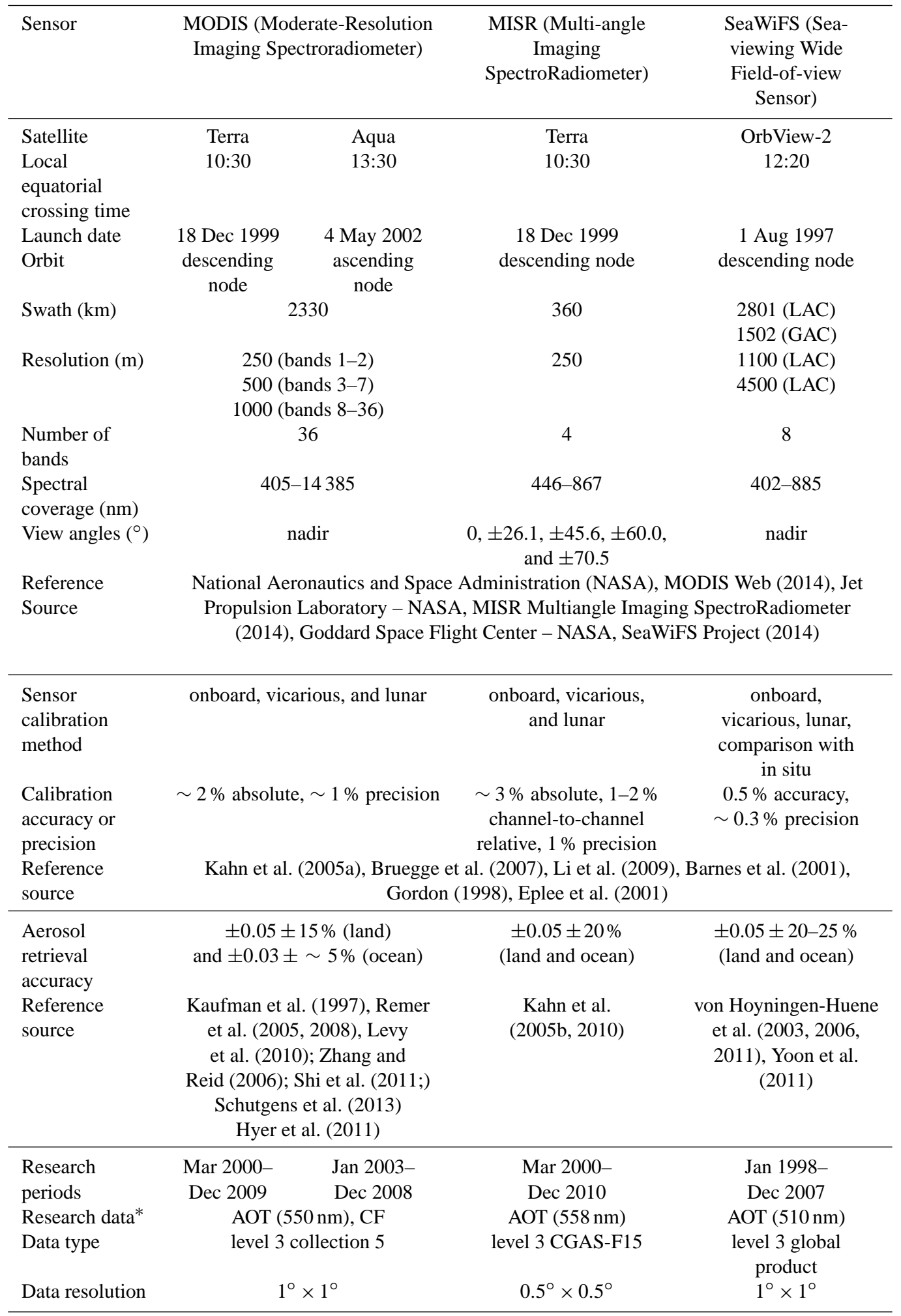

* AOT and CF: aerosol optical thickness and cloud fraction in daytime. 


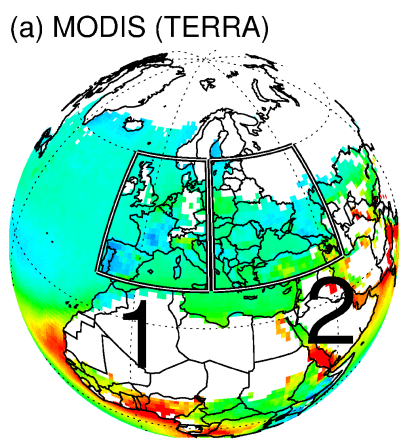

(c) SeaWiFS (OrbView-2)

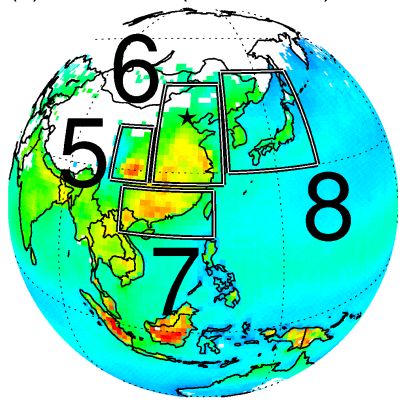

(b) MISR (TERRA)

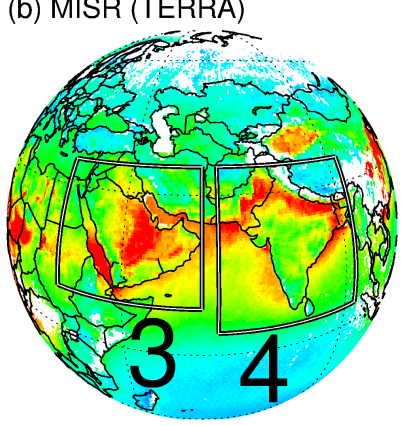

(d) MODIS (AQUA)

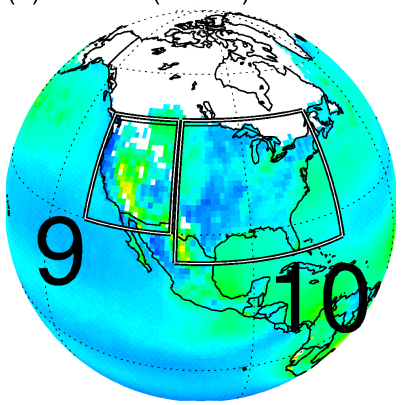

$\square$ No observation or not enough data

Aerosol Optical Thickness (AOT) [unitless]

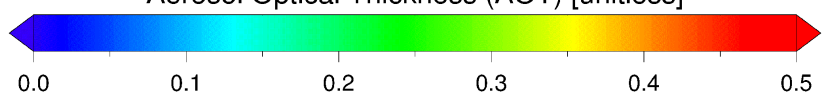

Figure 1. Plots of the mean values of (a) MODIS (Terra) AOT $(550 \mathrm{~nm})$ from March 2001 to December 2009, (b) MISR (Terra) AOT $(558 \mathrm{~nm})$ from March 2001 to December 2010, (c) SeaWiFS (OrbView-2) AOT (510 nm) from January 1998 to December 2007, and (d) MODIS (Aqua) AOT $(550 \mathrm{~nm})$ from January 2003 to December 2008 for the selected regions (1) western Europe, (2) eastern Europe, (3) the Middle/Near East, (4) southern Asia, (5) central China, (6) eastern China, (7) southern China, (8) Korea/Japan, (9) western USA, and (10) eastern USA. The black star in region 6 is the location of the AERONET station in Beijing. "No observation or not enough data" represents the discarded data series, which consist of less than seven monthly data points for a single year.

analysis. The monthly AOTs at $550 \mathrm{~nm}$ and cloud fraction (CF) from level 3 collection 5 global products $\left(1^{\circ} \times 1^{\circ}\right.$ spatial resolution) are used in this study.

\subsection{MISR (NASA Terra, March 2000-December 2010)}

The Multiangle Imaging SpectroRadiometer (MISR) (Jet Propulsion Laboratory - NASA, MISR Multiangle Imaging SpectroRadiometer, 2014) instrument, one of the sensors onboard the Terra spacecraft, provided Earth viewings in the visible wavelength range simultaneously at nine widely spaced angles. This unique feature enables different types of atmospheric aerosols, clouds, and land surface covers to be distinguished. In addition, the instrument provides global coverage at high spatial resolution (i.e., $275 \mathrm{~m} \times 275 \mathrm{~m}, 275 \mathrm{~m} \times 1.1 \mathrm{~km}, 1.1 \mathrm{~km} \times 1.1 \mathrm{~km}$ ), but it takes around 9 days to cover the entire Earth. The sensor is carefully calibrated ( $\sim 3 \%$ absolute, $1-2 \%$ channel-tochannel relative, $1 \%$ precision) (Kahn et al., 2005a; Bruegge et al., 2007) using onboard, vicarious, and lunar calibrations. This study uses monthly AOTs at $558 \mathrm{~nm}( \pm 0.05 \pm 20 \%$ over land and ocean) (Kahn et al., 2005b, 2010) from level 3 component global aerosol product version F15 (CGAS-F15) products $\left(0.5^{\circ} \times 0.5^{\circ}\right.$ spatial resolution $)$.

\subsection{SeaWiFS (NASA OrbView-2, January 1998 to December 2007)}

The Sea-viewing Wide Field Sensor (SeaWiFS) (Goddard Space Flight Center - NASA, SeaWiFS Project, 2014) on OrbView-2, launched in August 1997, continuously measured Earthshine radiances, which were well calibrated (accuracy: 0.5\%; stability: 0.3\%) (Li et al., 2009; Barnes et al., 2001; Gordon, 1998; Eplee et al., 2001) through use of onboard, lunar, and vicarious calibration procedures. In this study, SeaWiFS level 1B global-area coverage data (L1B GAC) are used for global AOT retrieval using the Bremen AErosol Retrieval (BAER) algorithm (von HoyningenHuene et al., 2003, 2006, 2011). It has been demonstrated that the BAER retrieval error ranges within $\pm 0.05 \pm 20$ $25 \%$ over land and ocean (von Hoyningen-Huene et al., 2011; Yoon et al., 2011). In this study, the AOT trends are estimated using monthly AOTs at $510 \mathrm{~nm}$ from the level 3 global product with $1^{\circ} \times 1^{\circ}$ spatial resolution.

All level 3 monthly products used in this study are aggregated and gridded using the level 2 daily products computed from the pixel-level retrievals with sufficiently high quality (Levy et al., 2009; Hsu et al., 2012; Di Girolamo et al., 2014; von Hoyningen-Huene et al., 2011). The process of aggregating and gridding level 2 products can lead to additional error in the trend estimates due to data loss during the process. Zhao et al. (2008) studied the uncertainty effect of gridlevel data in the long-term trend analysis of AVHRR AOT by comparing the results from grid-level data and pixel-level retrievals. They concluded that the differences are negligible not only in the seasonal/annual means but also in the resulting trend estimates.

\subsection{AERONET (AErosol RObotic NETwork)}

AERONET is a global network of ground-based aerosol remote sensing (i.e., Sun photometers) for monitoring aerosol optical properties at globally distributed stations and validating the aerosol products retrieved from satellite-borne measurements. It provides long-term records of cloud-free AOT (Remer et al., 1997; Dubovik et al., 2002) with high temporal resolution as well as high retrieval accuracy (Holben et al., 1998, 2001; Eck et al., 1999). In this study, level 2.0 AERONET AOTs are used not only to estimate uncertainty from temporal sampling limitations but also to validate the 


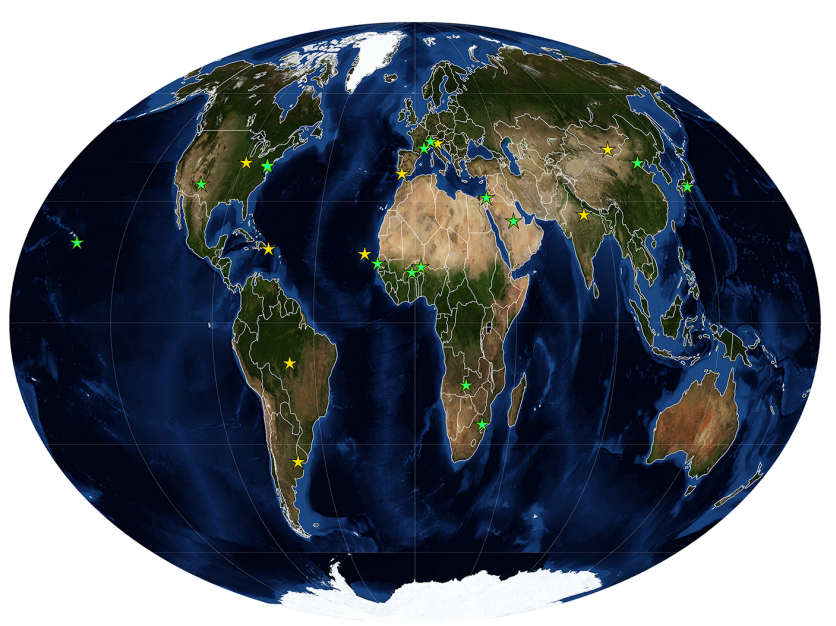

Figure 2. The AERONET stations used for estimating the uncertainty caused by limited/different temporal sampling and validating the satellite-retrieved AOT trends in this study. The yellow and green stars denote the AERONET stations with continuous yearly data for more than 3 and 5, respectively. These stations are listed on the Tables 2 and 4, respectively.

AOT trends derived from the satellite products. The selected AERONET stations are shown on a global map in Fig. 2.

\section{Different/limited temporal sampling of polar-orbiting satellites}

The reduction of the error and uncertainty in the trend analysis of cloud-free AOT, retrieved from measurements of the upwelling solar and thermal infrared spectrum by instruments on polar-orbiting satellites, has been achieved through a variety of approaches. This includes optimization of instrument calibration and the refinement of retrieval algorithms (Zhao et al., 2008; Karnieli et al., 2009; Mishchenko et al., 2007; Mishchenko and Geogdzhayev, 2007; Massie et al., 2004; Hsu et al., 2012). Thus far, no study has fully addressed the issue of the unrepresentative sampling induced by different/limited temporal sampling of the instruments. Adequate sampling is a prerequisite for deriving reliable and convincing trends. Even though the polar-orbiting satellites can cover the entire Earth for a single day, they cannot provide continuous sampling for a given location.

The temporal pattern correlations between different/limited samplings (at 10:30 $\pm 30 \mathrm{~min}$ for Terra, 12:20 $\pm 30 \mathrm{~min}$ for OrbView-2, and 13:30 $\pm 30 \mathrm{~min}$ for Aqua) and all available sampling were investigated using real-time AERONET AOTs at $550 \mathrm{~nm}$, which are determined from the retrieved AOTs at $440 \mathrm{~nm}$ by using knowledge of the Ångström exponent for the $440-675 \mathrm{~nm}$ region. Since there should be no difference in retrieval accuracy, cloud-filtering method, and spatial resolution for each AERONET station, the different pattern correlations are likely to be caused only by the different and limited temporal sampling. The AERONET stations were selected using the series of criteria as defined in Yoon et al. (2012) as follows:

1. The qualified monthly mean reflecting the parent population is calculated with the number of observations larger than 300 per month.

2. The complete yearly data set is composed of more than seven qualified monthly means in order to minimize a bias from data missing in the trend estimate.

3. The minimum temporal coverage for the trend estimate is a continuous 5-year set of the complete yearly data.

Figure 3 shows the Taylor diagram, which describes three statistical metrics in one plot, viz. temporal correlation, normalized standard deviation, and normalized centered rootmean-square (rms) difference of the two data sets (Taylor, 2001; Solomon et al., 2007; Meehl et al., 2007). The monthly AERONET AOTs are resampled at the local equatorial crossing times of the instruments for the temporal pattern correlation analysis. The AERONET stations used in Fig. 3 are classified by their regional dominant aerosol types (e.g., industrial/biomass burning, free troposphere, desert dust, and rural aerosols) and are listed in Table 2. The aerosol classification is explained in Yoon et al. (2012). At the stations influenced by desert and rural aerosols, the temporal pattern correlation is obtained for all the sampling times i.e. $0.91 \leq$ temporal $R \leq 0.98, \quad 0.87 \leq$ normalized temporal $\mathrm{STD} \leq 1.13$, and $0.19 \leq$ normalized centered $\mathrm{rms}$ difference $\leq 0.44$. In contrast, the correlation at the stations where industrial/biomass burning and free tropospheric aerosols are dominant is poorer $(0.72 \leq$ temporal $R \leq 0.94,0.78 \leq$ normalized temporal $\mathrm{STD} \leq 1.21$, and $0.36 \leq$ normalized centered rms difference $\leq 0.80$ ). As there is no difference in retrieval accuracy, cloud-filtering method, and spatial resolution, as previously mentioned, this difference can be only attributed to the different and limited sampling times and it can relate to diurnal variation of the aerosol sources (Smirnov et al., 2002; Kocha et al., 2013; Arola et al., 2013). In particular, the temporal correlation coefficient at the Beijing station ranges from 0.72 to 0.83 , and there is good chance of deriving different trends from the different/limited samplings over such a large urban agglomeration.

For a more detailed investigation at the Beijing station, Fig. 4 shows the linear trends derived using monthly AERONET AOTs $(550 \mathrm{~nm})$, which are calculated either from all available or resampled AERONET data. The figure shows that the trend estimates from different/limited temporal samplings can significantly differ from each other and from "actual trend". The difference is likely to be attributed to the different sampled population due to the different/limited temporal sampling as shown in Figs. 3 and 4.

To support it, let us suppose an ideal condition that AOT daily mean $\left(D^{N}\right)$ for $N$ th day is the sum of the sampled 
Table 2. The AERONET stations classified by regional dominant aerosol types (Yoon et al., 2012) for the investigation of the temporal pattern correlation in Fig. 3. The AERONET stations are selected using the criterion that the minimum length of the data set is 5 years (Yoon et al., 2012).

\begin{tabular}{lccrl}
\hline $\begin{array}{l}\text { AERONET } \\
\text { stations }\end{array}$ & $\begin{array}{c}\text { Geolocations } \\
\left(\text { lat. }\left[^{\circ}\right] / \text { long. }\left[^{\circ}\right] / \text { alt. }[\mathrm{m}]\right)\end{array}$ & $\begin{array}{c}\text { Research } \\
\text { periods }\end{array}$ & $\begin{array}{c}\text { Number } \\
\text { of months }\end{array}$ & $\begin{array}{l}\text { Dominant } \\
\text { aerosol type }\end{array}$ \\
\hline Avignon & $+43.93 /+4.88 / 32$ & $2001-2005$ & 59 & Industrial/biomass burning \\
Banizoumbou & $+13.54 /+2.66 / 250$ & $2002-2008$ & 84 & Desert \\
Beijing & $+39.98 /+116.38 / 92$ & $2003-2007$ & 59 & Industrial/biomass burning \\
Dakar & $+14.39 /-16.96 / 0$ & $2004-2008$ & 60 & Desert \\
GSFC & $+38.99 /-76.84 / 87$ & $1995-2008$ & 168 & Industrial/biomass burning \\
Ispra & $+45.80 /+8.63 / 235$ & $2001-2007$ & 83 & Industrial/biomass burning \\
Mauna_Loa & $+19.54 /-155.58 / 3397$ & $1998-2009$ & 144 & Free troposphere \\
MD_Science_Center & $+39.28 /-76.62 / 15$ & $2000-2006$ & 84 & Industrial/biomass burning \\
Mongu & $-15.25 /+23.15 / 1107$ & $2000-2004$ & 69 & Desert \\
Ouagadougou & $+12.20 /-1.40 / 290$ & $2000-2004$ & 59 & Desert \\
SEDE_BOKER & $+30.86 /+34.78 / 480$ & $2003-2008$ & 70 & Desert \\
Sevilleta & $+34.35 /-106.89 / 1477$ & $1998-2002$ & 58 & Rural \\
Shirahama & $+33.69 /+135.36 / 10$ & $2003-2009$ & 81 & Industrial/biomass burning \\
Skukuza & $-24.99 /+31.59 / 150$ & $2000-2007$ & 95 & Industrial/biomass burning \\
Solar_Village & $+24.91 /+46.40 / 764$ & $2001-2007$ & 82 & Desert \\
\hline
\end{tabular}

values $\left(S_{t_{n}}^{N}\right)$ divided by the number $(n)$ of sampling times $\left(t_{n}\right)$ :

$D^{N}=\frac{S_{t_{1}}^{N}+S_{t_{2}}^{N}+\ldots+S_{t_{n}}^{N}}{n}$.

Then the monthly mean $(M)$ is calculated using daily means as follows:

$$
\begin{aligned}
M & =\frac{D^{1}+D^{2}+\ldots+D^{N}}{N} \\
& =\frac{\frac{S_{t_{1}}^{1}+S_{t_{2}}^{1}+\ldots+S_{t_{n}}^{1}}{n}+\frac{S_{t_{1}}^{2}+S_{t_{2}}^{2}+\ldots+S_{t_{n}}^{2}}{n}+\ldots+\frac{S_{t_{1}}^{N}+S_{t_{2}}^{N}+\ldots+S_{t_{n}}^{N}}{n}}{N} \\
& =\frac{\frac{S_{t_{1}}^{1}+S_{t_{1}}^{2}+\ldots+S_{t_{1}}^{N}}{N}+\frac{S_{t_{2}}^{1}+S_{t_{2}}^{2}+\ldots+S_{t_{2}}^{N}}{N}+\ldots+\frac{S_{t_{n}}^{1}+S_{t_{n}}^{2}+\ldots+S_{t_{n}}^{N}}{N}}{n} \\
& \frac{1}{n}\left(M_{t_{1}}+M_{t_{2}}+\ldots+M_{t_{n}}\right) .
\end{aligned}
$$

In other words, the monthly mean $(M)$ is the average of the monthly means $\left(M_{t_{n}}\right)$ of the sampled values at the specific times $\left(t_{n}\right)$. The time series composed of the monthly means is expressed as a vector equation as follows:

$\vec{M}=\frac{1}{n}\left(\vec{M}_{t_{1}}+\vec{M}_{t_{2}}+\ldots+\vec{M}_{t_{n}}\right)$.

The temporal change/trend is given by the partial differential of Eq. (3) as follows:

$\frac{\partial \vec{M}}{\partial t}=\frac{1}{n}\left(\frac{\partial \vec{M}_{t_{1}}}{\partial t}+\frac{\partial \vec{M}_{t_{2}}}{\partial t}+\ldots+\frac{\partial \vec{M}_{t_{n}}}{\partial t}\right)$.

Finally, the "actual trend" $\left(\frac{\partial \vec{M}}{\partial t}\right)$ is identical to the average of AOT trends $\left(\frac{\partial \vec{M}_{t_{n}}}{\partial t}\right)$ at each time $\left(t_{n}\right)$, and it also presents a potential possibility that AOT can change differently at each time of day because of different changes in anthropogenic emissions, secondary production, meteorological transport, etc.

Table 3 lists the relative percentage errors to the actual trend at the selected AERONET stations. Except for the Mongu station (because of an almost negligible actual trend), the stations influenced by industrial or biomass burning aerosols (i.e., Avignon, Beijing, GSFC, Ispra, MD_Science_Center, Shirahama, and Skukuza) have larger relative errors ( -156 to $399.2 \%$ ) than the stations (Banizoumbou, Dakar, Ouagadougou, SEDE_BOKER, and Solar_Village) near desert regions $(-63.6$ to $+59.3 \%)$. At the Mauna_Loa (in free troposphere and open ocean) and Sevilleta stations (rural region), the relative errors range from $-100.0 \%$ to $0.0 \%$. These errors demonstrate that the trend estimate from different/limited temporal sampling can be different to the actual trend. In addition, Fig. 5 shows the comparisons between the AERONET-resampled trends. The uncertainty is more serious over the regions where industrial or biomass burning aerosols are dominant, and thereby it is possible to derive different or contradictory trends to the actual trend. Generally, the AERONET-resampled trends are underestimated by 24 to $36 \%$. This knowledge is important for understanding the difference in the AOT trends from the different/limited temporal sampling of the satellite data.

\section{Weighted trend model for considering cloud disturbance}

An insufficient number of AOT retrievals induced by cloud occurrence in the instrument field of view can cause a bias 

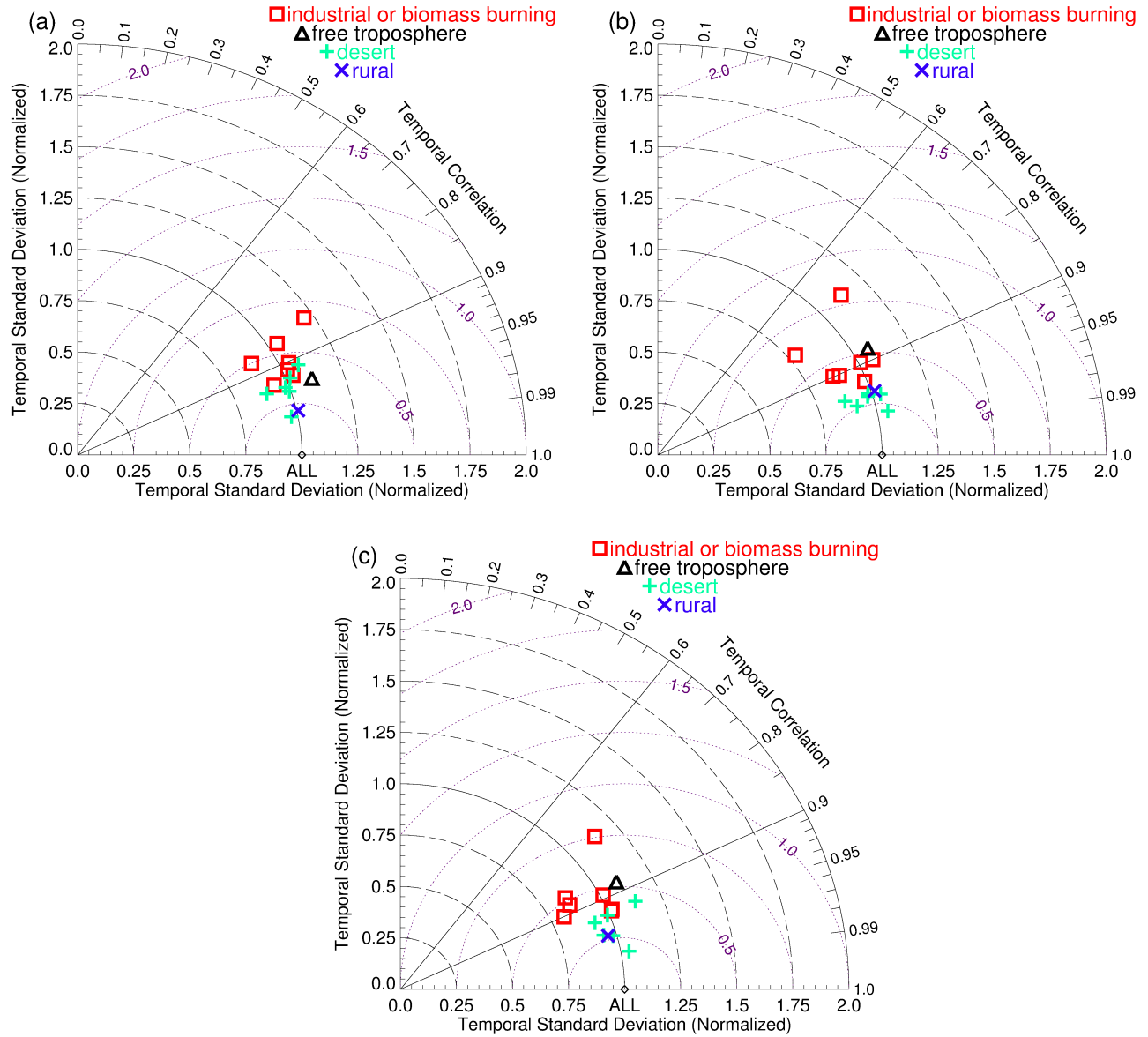

Figure 3. Taylor diagrams for analyzing temporal pattern correlations between monthly means of different/limited sampling ((a) 10:30 $\pm 30 \mathrm{~min}$, (b) 12:20 $\pm 30 \mathrm{~min}$, and (c) 13:30 $\pm 30 \mathrm{~min}$ ) and all available sampling using the real-time AERONET AOT (550 nm) data. The normalized centered root-mean-square (rms) difference is proportional to the distance from the point "ALL" on the $x$ axis (i.e., shown as purple dashed semicircles). The AERONET stations are classified by regional dominant aerosol types - industrial/biomass burning, free tropospheric, desert, and rural aerosols (Yoon et al., 2012) - and listed in Table 2.

in the trend estimate since it is a significant influence on the statistical representativeness of monthly AOT means (Yoon et al., 2011). Therefore, to derive an accurate and reliable change/trend estimate of atmospheric AOTs, the impact of cloud disturbance needs to be considered. The cloud occurrence generally leads to a decrease of the retrieval/observation number $\left(n_{t}\right)$ of cloud-free AOT (Kim et al., 2014; Kaufman et al., 1997; Remer et al., 2005, 2008; Levy et al., 2010; Kahn et al., 2005b, 2010; von HoyningenHuene et al., 2003, 2006, 2011; Yoon et al., 2007, 2011, 2012). A relatively large standard deviation compared to the mean $\left(\sigma_{t} / y_{\mathrm{t}}\right)$ is a good indicator of unrepresentativeness of the mean value, with cloud contamination in the cloud-free AOT retrieval being one possible cause (Yoon et al., 2007, 2011). Therefore, the combination of two quantities $\left(\sqrt{n_{t}} /\left(\sigma_{t} / y_{\mathrm{t}}\right)\right)$ can effectively minimize the uncertainty from cloud disturbance and unrepresentative data in the change/trend analysis of cloud-free global AOT (Yoon et al., 2012), and is used as a weighting factor in this study. The monthly AOTs $\left(y_{t}\right)$ are used for fitting the linear regression, where $\chi^{2}$ is minimized by

$$
\chi^{2}(A, B)=\Sigma_{t=1}^{T}\left(w t_{t} \times\left(y_{\mathrm{t}}-A-B x_{t}-\tilde{y}^{\mathrm{m}}\right)\right)^{2},
$$

where $w t_{t}$ is the monthly weighting factor $\left(\sqrt{n_{t}} /\left(\sigma_{t} / y_{\mathrm{t}}\right)\right), t$ is time in months $(t=1 \ldots T), A$ is a constant term, $B$ is the magnitude of the trend per year $\left(x_{t}=t / 12\right), n_{t}$ is the number of observations per month, $y_{\mathrm{t}}$ is the monthly mean of all AOT measurements, and $\sigma_{t}$ is the standard deviation of the monthly AOTs. $\tilde{y}^{\mathrm{m}}$ represents the mean of total $y_{\mathrm{t}}$ for each month $(m=1 \ldots 12)$ (i.e., the climatological monthly varying pattern in AOT) and accounts for the seasonal/natural AOT cycle in the trend estimation.

Figure 6 shows the simple linear and weighted changes/trends, as well as means and standard deviations of cloud fractions (CFs) derived from MODIS (Terra) products (March 2001-December 2009). The simple linear and weighted trends shown in Fig. 6a and b are generally consistent. However, in terms of the intensity and tendency, 
Table 3. Trend estimates of AERONET AOT $(550 \mathrm{~nm})$ from different sampling times (10:30 $\pm 30 \mathrm{~min}$ for Terra, 12:20 $\pm 30 \mathrm{~min}$ for OrbView2, and 13:30 $\pm 30 \mathrm{~min}$ for Aqua, and all available samplings) and corresponding relative errors.

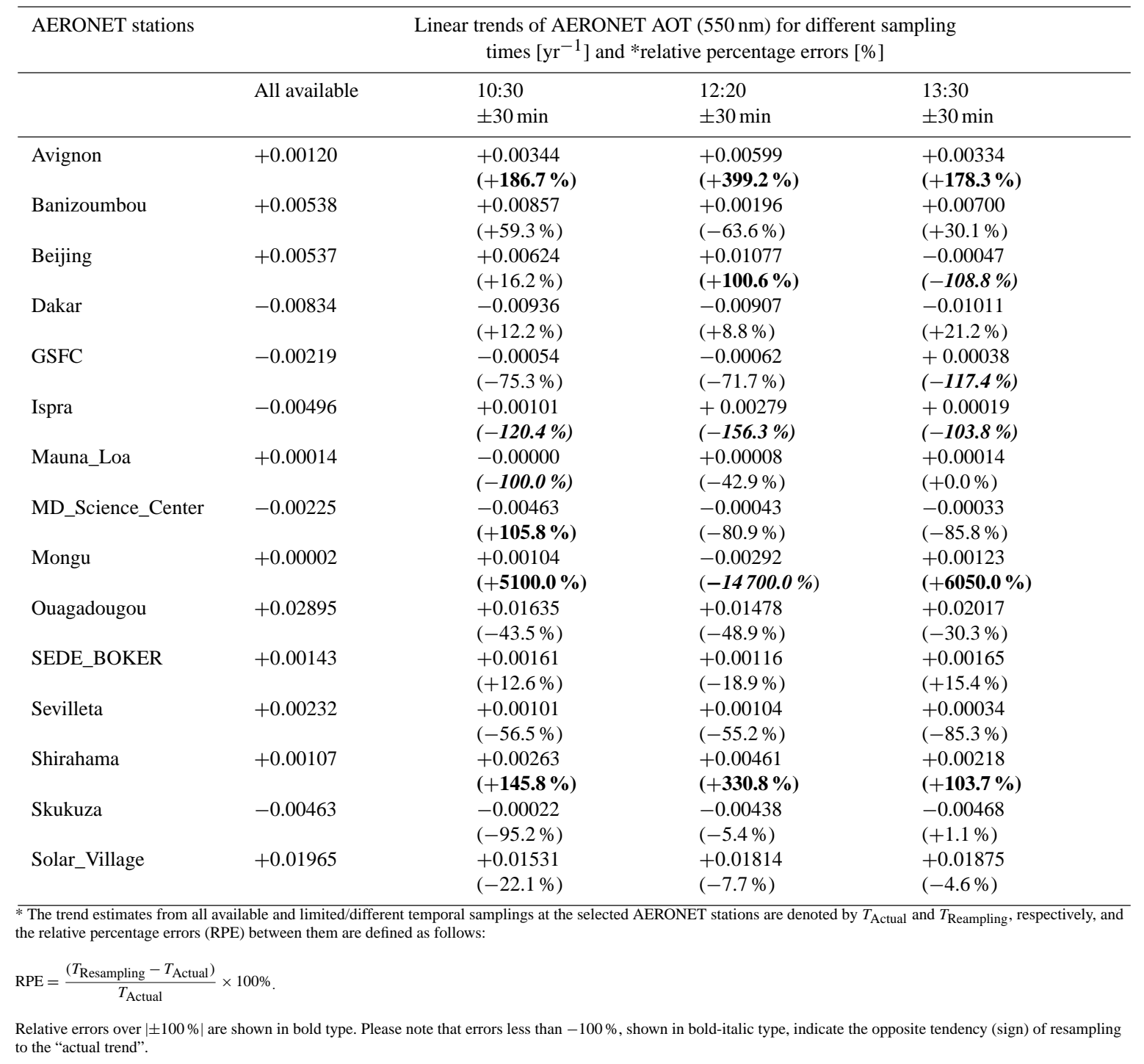

significant differences are found predominantly over regions with large CF variability in Fig. 6c:

i. A clear spatial division of the AOT trends in Fig. 6a is found near coastal locations, i.e., across the landsea boundary, even though they have a common source of continental aerosol. The pattern of increasing trends over the Indian subcontinent is often different across its land and ocean boundaries.

ii. There is no positive signal over Brazil even though it is one of the BRICs (a group of countries - Brazil, Russia, India, and China - with advanced economic development; Goldman Sachs, 2003). In spite of efforts to diminish the impact of slash-and-burn deforestation since 2001 in Brazil (Davidson and Artaxo, 2004; Kirby et al., 2006), significant amounts of atmospheric aerosol are expected to be produced by anthropogenic activity.

iii. The simple linear AOT trends in Fig. 6a show a clear discontinuity between land and surrounding ocean areas over southern Africa and southeastern Asia.

These findings are indicative of either instrumental (e.g., platform characteristics, sensor calibration, etc.), retrieval (AOT retrieval accuracy), or sampling/atmospheric issues (changes resulting from human activity or natural phenomena). Nonetheless, as mentioned above, one important systematic source of error for the trend estimate of cloud-free AOT can be attributed to cloud disturbance. Thus the trend estimate is expected to be less robust over regions where frequent cloud occurrence persists throughout the year, as shown in Fig. 6c and d, e.g., most of the marine areas or 


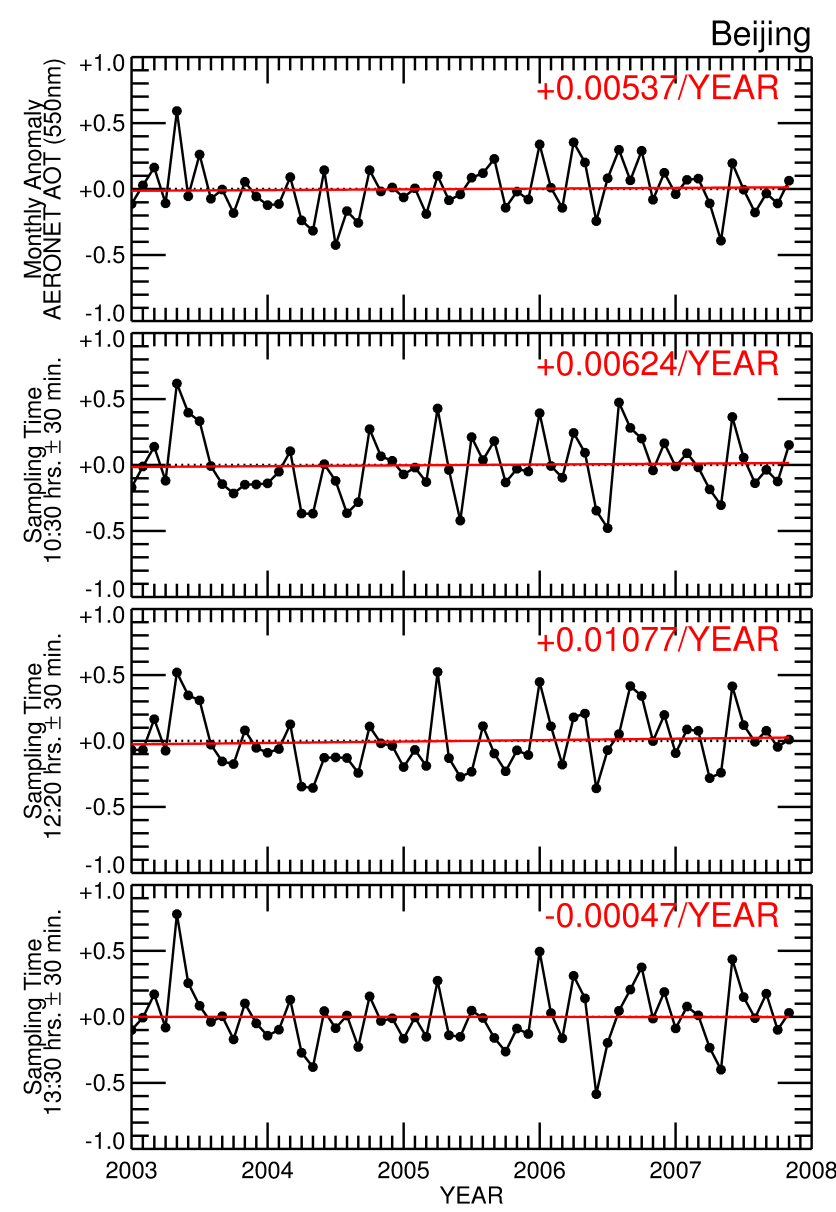

Figure 4. Time series of monthly anomaly of AERONET AOTs $(550 \mathrm{~nm})$ (i.e., all available data or those sampled at 10:30 $\pm 30 \mathrm{~min}$, 12:20 $\pm 30 \mathrm{~min}$, and 13:30 $\pm 30 \mathrm{~min}$.) from 2003 to 2007 and corresponding trend estimates at Beijing station.

tropical rain/cloud forests around the Intertropical Convergence Zone (ITCZ).

For the problematic regions shown in Fig. 6a, the discontinuities of the MODIS-Terra AOT trend between land and ocean over southern Asia, southeastern Asia, and southern Africa have disappeared, and a positive trend is now found over South America in Fig. 6b. Over the majority of the ocean, a continuous cloud occurrence disturbs sufficient samplings all year around, as shown in Fig. 6c and d, and the derivation of statistically significant AOT trends over oceans is therefore limited by this issue. Consequently, for the regional trend estimate of cloud-free AOT, the present study focuses on those regions which are not significantly influenced by cloud disturbance as selected and shown in Fig. 1 .

\subsection{Outlier tests of the weighting factors}

The weighted trend model defined in Eq. (5) is very sensitive to the outliers in weighting factors. The outliers occur due to very small or large standard deviation compared to the mean value; the small standard deviation is generally attributed to the small number of observations and the large one is caused by the high variability in aerosol itself. To remove outliers from the weighting factors, we use the Grubbs test (Grubbs, 1969) and Gaussian test within a $95 \%$ confidence level. Firstly, the Grubbs test is used to detect outliers based on the assumption that an approximately normal distribution is the most probable distribution:

$$
\begin{aligned}
G_{i} & >(N-1) / N \sqrt{t_{(\alpha / N, N-2)}^{2} /\left(N-2+t_{(\alpha / N, N-2)}^{2}\right)} \\
& \text { with } G_{i}=\left(w t_{i}-\mu_{w t}\right) / \sigma_{w t},
\end{aligned}
$$

where $N, \mu_{w t}$, and $\sigma_{w t}$ are the number, mean, and standard deviation of total $w t_{i}$, respectively. $t_{(\alpha / N, N-2)}^{2}$ denotes the critical value of the $t$ distribution with $(N-2)$ degrees of freedom and a significance level of $(\alpha / N)$. If the weighting factor satisfies Eq. (6), it is rejected as an outlier. After removing outliers by using the Grubbs test, the remaining weighting factors follow a Gaussian distribution. In a second step, the hypothesis of no outliers within a $95 \%$ confidence level is discarded if $w t_{i}$ satisfies the following Eq. (7):

$w t_{i}>\mu_{w t}+2 \sigma_{w t}$ or $w t_{i}<\mu_{w t}-2 \sigma_{w t}$.

Using these statistical tests and assumptions, outliers in the weighting factors are successfully removed. Figure 7 illustrates an example of the outlier tests for significant weighting factors at the GSFC AERONET station from 1993 to 2009. In this case, 9 outliers are filtered out and 187 significant weighting factors remain after the tests.

\subsection{Significance test of the weighting trends}

For a statistically meaningful analysis of regional AOT trends, the present study takes into account the weighted trend $\left(B_{\mathrm{g}}\right)$ for each grid cell $\left(1^{\circ} \times 1^{\circ}\right.$ for MODIS and SeaWiFS or $0.5^{\circ} \times 0.5^{\circ}$ for MISR) within a $95 \%$ confidence level. The significant trend is determined by the significance $\left(\left|B_{\mathrm{g}} / \sigma_{B_{\mathrm{g}}}\right|\right)$ larger than 2 (Weatherhead et al., 1998, 2002). The standard deviation of the gridded trend $\left(\sigma_{B_{\mathrm{g}}}\right)$ is estimated using the bootstrap method (Mudelsee, 2010) (i.e., Monte Carlo error bar analysis), using 5000 resampling iterations of monthly AOT anomalies for each grid (i.e., 5000 bootstrapresample trends from 5000 bootstrap-resample data sets).

\section{Trend validation with AERONET observation}

The weighted trends derived from the satellite AOT products as described in Sect. 4 have been validated by comparing with the AERONET trends at the stations, listed in Table 4 . Figure 8 shows the scatter plots and correlation analysis. The AERONET stations are selected with the criterion that there are more than 3 years of continuous observation, which has been defined in Sect. 3. The 3-year time span 

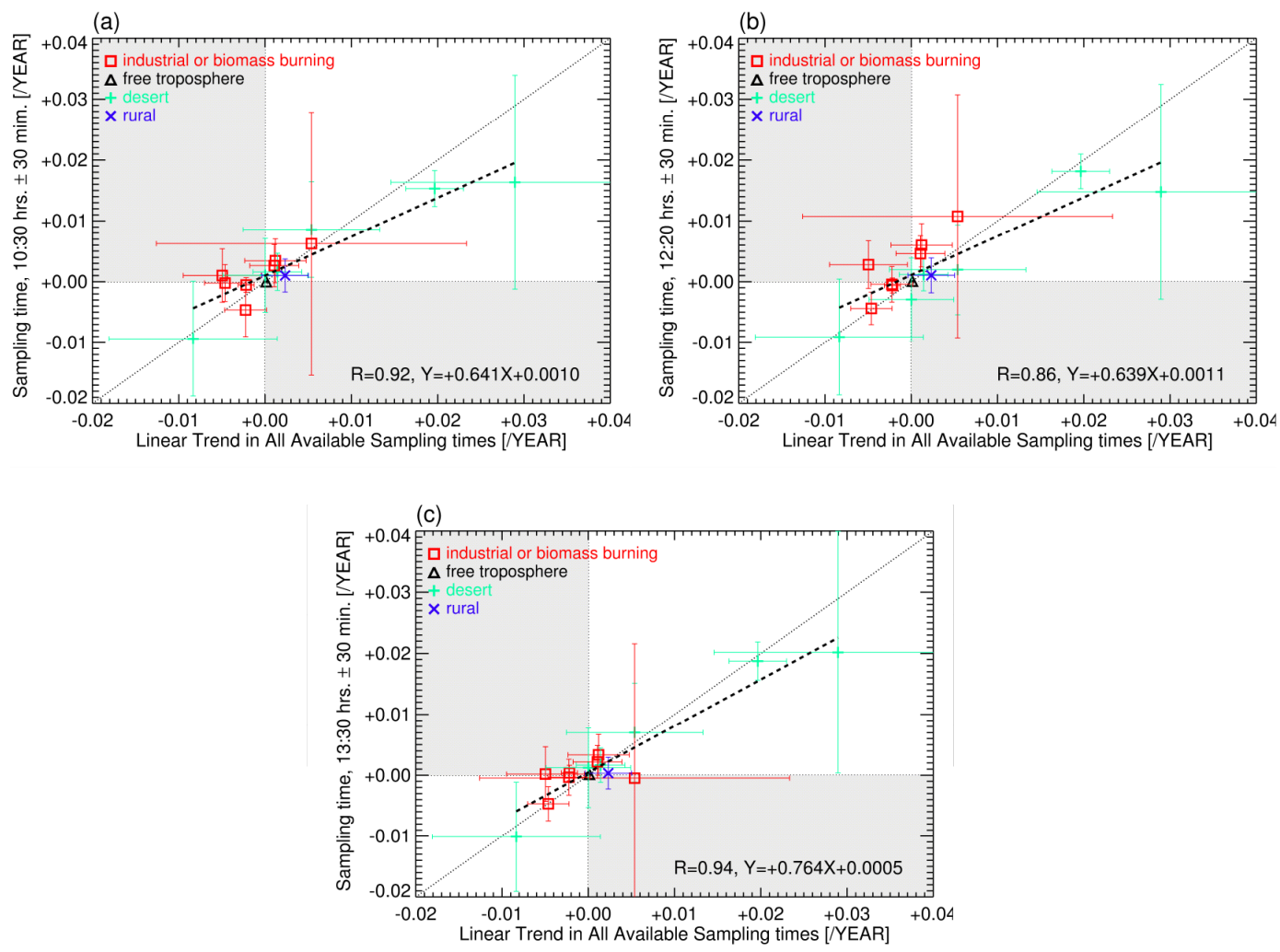

Figure 5. Scatter plots of comparison between the linear trends of all available measurements and those sampled around (a) 10:30 \pm 30 min, (b) 12:20 $\pm 30 \mathrm{~min}$, and (c) 13:30 \pm 30 min using the real-time AERONET AOT (550 nm) data.

may be insufficiently short for the trend estimation, but it is practical for trend validation over global area. Since the AERONET monthly AOT is calculated from all available samplings, the AOT trends derived from satellite observations are expected to be different compared to the AERONET AOT trends, at least due to different and limited sampling times as discussed in Sect. 3 (i.e., around 24 to $36 \%$ underestimation in the "ideal satellite-derived trend" compared to the actual trend). In summary, from this comparison we can show how different the satellite-derived trends are compared to the AERONET AOT trends, i.e., actual trends.

In Fig. 8a and b, the AERONET AOT trend shows a better correlation with the MODIS (Terra) trend than with the MISR trend. This is partly explained by MISR long revisiting cycle (i.e., global coverage time is 7-9 days due to $360 \mathrm{~km}$ of swath width) compared to MODIS (global coverage time: 1-2 days; swath width: $2330 \mathrm{~km}$ ), even though MODIS and MISR are onboard the same space platform, Terra. However only MISR provides the available trend estimates over desert regions in this study. This is because the MISR algorithm retrieves AOT over the highly reflective surfaces using its multiple-viewing observations (Kahn et al., 2007, 2010). The weighted trends of the SeaWiFS/BAER and AERONET AOTs are highly correlated $(R=0.8)$, as shown in Fig. 8c. However, the low slope of the linear fit might be attributed to either an underestimation of SeaWiFS AOT (up to $20 \%$ near heavily polluted areas as a result of absorbing aerosols) (von Hoyningen-Huene et al., 2011), an OrbView-2 orbital drift (about $2 \mathrm{~h}$ of delay until the end of 2007) (Yoon et al., 2011), or the strict cloud-filtering method applied in BAER (von Hoyningen-Huene et al., 2011; Yoon et al., 2011). In contrast, the linear fit between the weighted trends of MODIS (Aqua) and AERONET AOTs shows a higher slope of 0.7 but rather poorer correlation ( $R=0.6)$, as shown in Fig. $8 \mathrm{~d}$. Major discrepancies between the AOT trends derived from satellite- and ground-based observations are likely due to many uncertainties in the AOT retrieval, e.g., sensor calibration status, retrieval accuracy, and cloud contamination (Zhao et al., 2008; Li et al., 2009; Yu et al., 2009; Zhang and Reid, 2010; Karnieli et al., 2009; Yoon et al., 2011; Hsu et al., 2012; de Meij et al., 2012). In addition, these discrepancies can be attributed to different sampling times and limited orbital periods, as demonstrated in Sect. 3 .

\section{Regional trend estimate}

Figures 9 and 10 show the global significances of weighted trends and statistically significant trends within a $95 \%$ confidence level (see Sect. 4.2). In this study, the significant trends of cloud-free AOTs from the individual instruments 

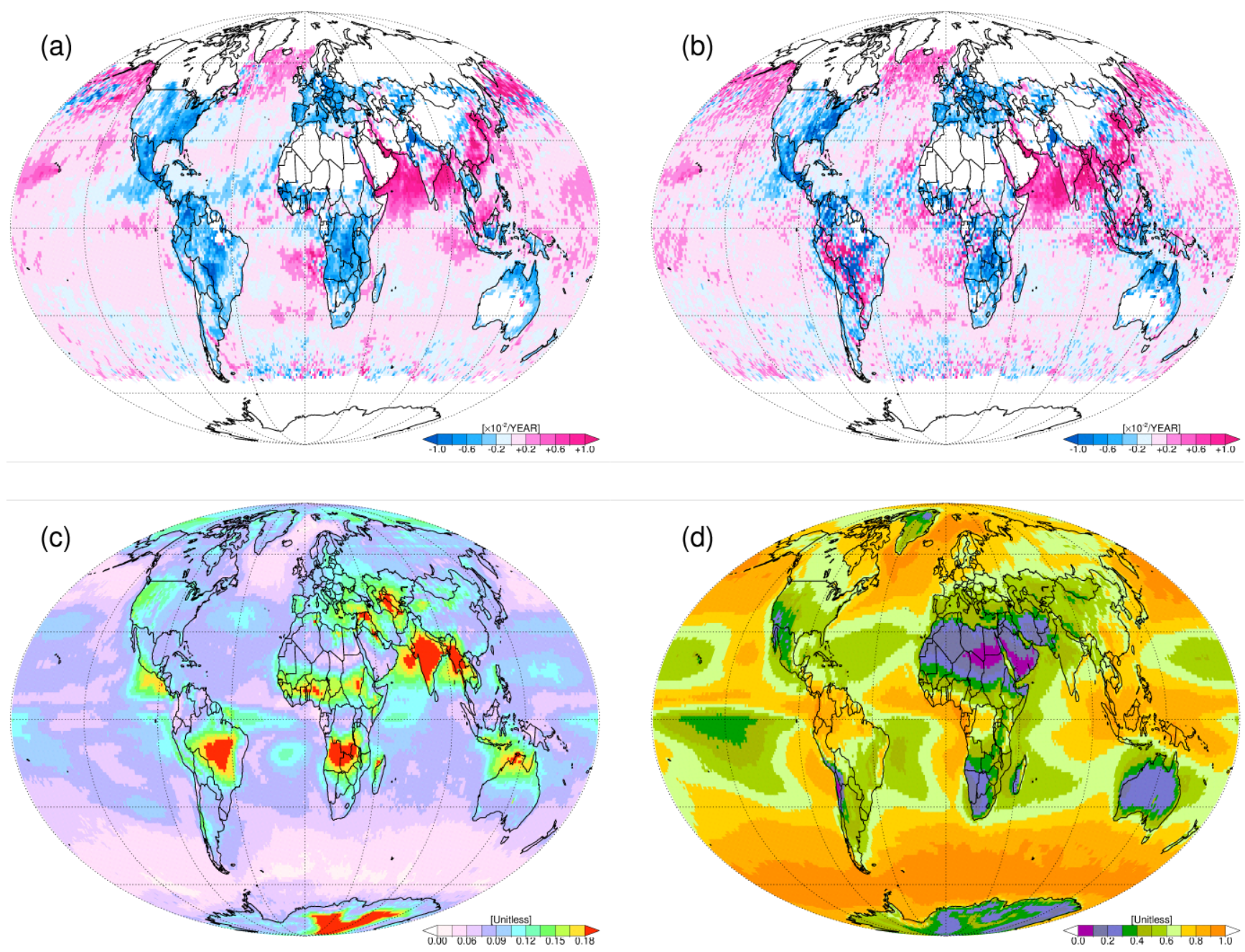

Figure 6. (a) Simple linear and (b) weighted trends of AOT $(550 \mathrm{~nm})$ from MODIS (Terra) observations from March 2001 to December 2009. The standard deviation and mean of total cloud fractions in daytime for the same periods are shown in (c) and (d).

(i.e., MODIS-Terra from March 2001 to December 2009, MISR-Terra from March 2001 to December 2010, SeaWiFSOrbView-2 from January 1998 to December 2007, and MODIS-Aqua from January 2003 to December 2008) are only used for the regional trend estimates as shown in Fig. 11. Over Europe, regions 1 and 2 in Fig. 1, various types of atmospheric aerosol are observed, i.e., anthropogenic pollutant from traffic, industrial, and urban sources (Marmer et al., 2007; Karnieli et al., 2009), biomass burning aerosol emitted from forest fires mostly in summer (Pace et al., 2006; Tafuro et al., 2008), and dust transported from northern African deserts in spring/summer (Hatzianastassiou et al., 2009). In particular, for western Europe, many previous studies reported that AOT from industrial and traffic sources significantly decreases, for example $-0.0027 \pm 0.0014 \mathrm{yr}^{-1}$ from 1997 to 2010 (Hsu et al., 2012), -9 to $-30 \%$ from 2000 to 2009 (de Meij et al., 2012), and -2.25 to $-2.78 \% \mathrm{yr}^{-1}$ at the Ispra AERONET station (Yoon et al.,
2012). This tendency is attributed to the success of environmental regulation in EU countries (Streets et al., 2003; Yoon et al., 2011, 2012; Hilboll et al., 2013). The weighted trends of satellite-retrieved AOTs range from $-1.41 \pm 1.09$ to $-6.59 \pm 5.30 \% \mathrm{yr}^{-1}$. Over eastern Europe, region 2, large emissions of smoke aerosols from summer peat/forest fires and industrial pollutants from urban areas have been reported (Korontzi et al., 2006; Hayn et al., 2009; Yoon et al., 2011; Chubarova et al., 2011, 2012; Barnaba et al., 2011; Zhou et al., 2012; Giles et al., 2012; Bovchaliuk et al., 2013). Overall, AOT decreases in this region $\left(-3.70 \pm 2.55 \% \mathrm{yr}^{-1}\right.$ for MODIS-Terra, $-1.17 \pm 0.93 \% \mathrm{yr}^{-1}$ for MISR-Terra, and $-1.32 \pm 1.00 \% \mathrm{yr}^{-1}$ for SeaWiFS-OrbView-2 AOT). This is comparable to the results over eastern Europe reported in Karnieli et al. (2009) and de Meij et al. (2012), i.e., $-38 \%$ of MODIS-Terra AOT from 2000 to 2007, -43\% of groundbased AOT observation from 1998 to 2007, and -5 to $-25 \%$ of MODIS-Terra, MISR-Terra, and AERONET AOT from 
Table 4. Geolocations of AERONET stations and research periods of AERONET level 2.0 AOT data for the validations of the satellite-derived trends in Fig. 8.

\begin{tabular}{|c|c|c|c|c|}
\hline $\begin{array}{l}\text { AERONET } \\
\text { stations }\end{array}$ & $\begin{array}{l}\text { Geolocations } \\
\left.\text { (lat. }\left[^{\circ}\right] / \text { long. }\left[^{\circ}\right] / \text { alt. }[\mathrm{m}]\right)\end{array}$ & Countries & $\begin{array}{l}\text { Research } \\
\text { periods }\end{array}$ & $\begin{array}{l}\text { Targets for } \\
\text { trend validation }^{b}\end{array}$ \\
\hline Alta_Floresta & $-9.87 /-56.10 / 277$ & Brazil & 2001-2004 & MOD, SEA \\
\hline Avignon & $+43.93 /+4.88 / 32$ & France & 2003-2005 & $\begin{array}{l}\text { MOD, MIS, SEA, } \\
\text { MYD }\end{array}$ \\
\hline Banizoumbou $^{\mathrm{a}}$ & $+13.54 /+2.66 / 250$ & Niger & 2003-2008 & MIS \\
\hline Beijing & $+39.98 /+116.38 / 92$ & China & 2004-2007 & $\begin{array}{l}\text { MOD, MIS, SEA, } \\
\text { MYD }\end{array}$ \\
\hline BONDVILLE & $+40.05 /-88.37 / 212$ & USA & 2002-2006 & $\begin{array}{l}\text { MOD, MIS, SEA, } \\
\text { MYD }\end{array}$ \\
\hline Capo_Verde & $+16.73 /-22.94 / 60$ & Sal Island & $2005-2008$ & $\begin{array}{l}\text { MOD, MIS, SEA, } \\
\text { MYD }\end{array}$ \\
\hline CEILAP-BA & $-34.57 /-58.50 / 10$ & Argentina & $2000-2007$ & MOD, SEA, MYD \\
\hline Dakar $^{\mathrm{a}}$ & $+14.39 /-16.96 / 0$ & Senegal & 2004-2007 & MIS \\
\hline Dalanzadgad $^{\mathrm{a}}$ & $+43.58 /+104.42 / 1470$ & Mongolia & 1999-2004 & MIS \\
\hline El_Arenosillo & $+37.11 /-6.73 / 0$ & Spain & 2002-2005 & $\begin{array}{l}\text { MOD, MIS, SEA, } \\
\text { MYD }\end{array}$ \\
\hline GSFC & $+38.99 /-76.84 / 87$ & USA & 1998-2008 & $\begin{array}{l}\text { MOD, MIS, SEA, } \\
\text { MYD }\end{array}$ \\
\hline Ispra & $+45.80 /+8.63 / 235$ & Italy & 2001-2007 & $\begin{array}{l}\text { MOD, MIS, SEA, } \\
\text { MYD }\end{array}$ \\
\hline Kanpur & $+26.51 /+80.23 / 123$ & India & 2001-2006 & $\begin{array}{l}\text { MOD, MIS, SEA, } \\
\text { MYD }\end{array}$ \\
\hline La_Parguera & $+17.97 /-67.05 / 12$ & Puerto Rico & 2006-2009 & MOD, MIS, MYD \\
\hline Mauna_Loa & $+19.54 /-155.58 / 3397$ & USA & 1998-2009 & $\begin{array}{l}\text { MOD, MIS, SEA, } \\
\text { MYD }\end{array}$ \\
\hline MD_Science_Center & $+39.28 /-76.62 / 15$ & USA & 2000-2006 & $\begin{array}{l}\text { MOD, MIS, SEA, } \\
\text { MYD }\end{array}$ \\
\hline Mongu & $-15.25 /+23.15 / 1107$ & Zambia & 1999-2008 & $\begin{array}{l}\text { MOD, MIS, SEA, } \\
\text { MYD }\end{array}$ \\
\hline Ouagadougou $^{\mathrm{a}}$ & $+12.20 /-1.40 / 290$ & Burkina Faso & 2000-2004 & MIS \\
\hline SEDE_BOKER $^{\mathrm{a}}$ & $+30.86 /+34.78 / 480$ & Israel & 2004-2008 & MIS \\
\hline Shirahama & $+33.69 /+135.36 / 10$ & Japan & 2002-2009 & $\begin{array}{l}\text { MOD, MIS, SEA, } \\
\text { MYD }\end{array}$ \\
\hline Skukuza & $-24.99 /+31.59 / 150$ & southern Africa & 2001-2007 & $\begin{array}{l}\text { MOD, MIS, SEA, } \\
\text { MYD }\end{array}$ \\
\hline Solar_Village $^{\mathrm{a}}$ & $+24.91 /+46.40 / 764$ & Saudi Arabia & 2001-2007 & MIS \\
\hline Venice & $+45.31 /+12.51 / 10$ & Italy & 2000-2005 & MOD, SEA, MYD \\
\hline
\end{tabular}

a AERONET stations used for the trend validation of MISR AOT only.

b MOD, MIS, SEA, and MYD are abbreviations for MODIS (Terra), MISR (Terra), SeaWiFS (OrbView-2), and MODIS (Aqua).

2000 to 2009. According to Karnieli et al. (2009), the decreases result from changes in the vehicle fleet and industrial practices, leading to a $25 \%$ reduction of fine aerosols' mass from 1995 to 2004 . However, in contrast a significant temporal increase of MODIS (Aqua) AOT is observed in the afternoon $\left(+4.66 \pm 3.82 \% \mathrm{yr}^{-1}\right)$. In this context, positive trends of $\mathrm{NO}_{2}$ emissions over eastern Europe in the afternoon have been identified (Zhou et al., 2012; Streets et al., 2006); similarly, burned area from Global Fire Emissions Database (GFED) (Giglio et al., 2010) increases over eastern Europe for the period 2004 to 2008, as shown in Fig. 12. It should be noted that only different/limited temporal sampling is able to yield different trend estimates, as demonstrated in Sect. 3.

Cities in the Near/Middle East, such as Cairo, exhibit some of the highest local air pollution levels due to a combination of increasing population, intense fossil fuel combustion, and poorly regulated vehicle emissions (Kanakidou et al., 2011). In addition, mineral dust transported from the Sahara and Arabian deserts is a dominant aerosol type over the Near/Middle East (Sabbah et al., 2006; Zhao et al., 2008; Yoon et al., 2012), region 3 in Fig. 1. Significant amounts of fine-mode aerosols produced by the petroleum industry and related shipping activities are observed (Basart et al., 


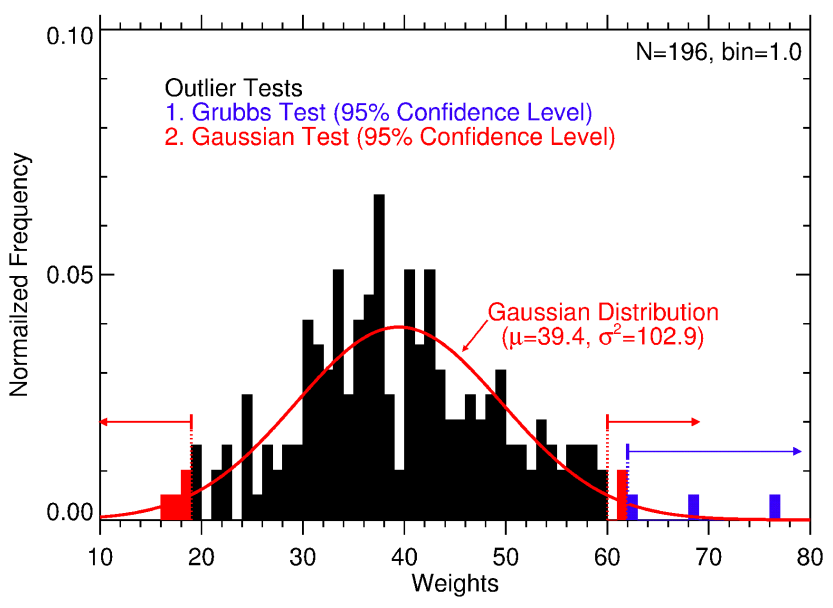

Figure 7. An example of outlier tests (Grubbs and Gaussian tests) within a $95 \%$ confidence level using monthly AERONET data at GSFC from 1993 to 2009 . The frequency of weights is normalized to total number $(N)$. In this case, 9 outliers are filtered out and 187 significant weighting factors remain after the outlier tests.

2009; Yoon et al., 2012). Franke et al. (2009) and Richter et al. (2004) also reported the emissions from fossil fuel combustion by ships passing through the Suez Canal and Red Sea. The trend in the Near/Middle East shows a significant increase (i.e., $+1.63 \pm 1.07 \% \mathrm{yr}^{-1}$ for MODIS-Terra, $+2.74 \pm 1.78 \% \mathrm{yr}^{-1}$ for MISR-Terra, $+1.72 \pm 1.13 \% \mathrm{yr}^{-1}$ for SeaWiFS-OrbView-2 AOT, and $+3.84 \pm 2.66 \% \mathrm{yr}^{-1}$ for MODIS-Aqua). This has been explained by increases of coarse-mode aerosols from deserts $\left(+3.37 \% \mathrm{yr}^{-1}\right.$ for coarse-mode dominant AOT from 2001 to 2007 at the Solar_Village station, Yoon et al., 2012) and fine-mode aerosols from oil production, refining, and other industry in and around the Red Sea and the Persian Gulf (Sadrinasab and Kämpf, 2004). The increasing trends are comparable to the results; $+0.0092 \pm 0.0026 \mathrm{yr}^{-1}$ from 1997 to 2010 over the Arabian Peninsula (Hsu et al., 2012), +5 to $+23 \%$ from 2000 to 2009 over the Middle East (de Meij et al., 2012), and $64 \%$ enlargement of transported freight volume by ship through the Suez Canal between June 2003 and June 2008 (de Ruyter de Wildt et al., 2012).

Aerosol over the Indian subcontinent, as shown in region 4 in Fig. 1, is increasing. Here, AOT is influenced by a variety of emission sources, e.g., fossil fuel combustion, domestic burning of biofuels, biomass burning, forest fires, mineral dust, and maritime aerosol (Dey et al., 2004; Ramanathan et al., 2007a, b). Significant AOT increases are observed in all four data sets during the observation periods $\left(+2.38 \pm 1.49 \% \mathrm{yr}^{-1}\right.$ for MODIS-Terra, $+2.50 \pm 1.82 \% \mathrm{yr}^{-1}$ for MISR-Terra, $+1.52 \pm 1.07 \% \mathrm{yr}^{-1}$ for SeaWiFS-OrbView-2 AOT, and $+4.77 \pm 3.21 \% \mathrm{yr}^{-1}$ for MODIS-Aqua). These increases are comparable with the results, +0.02 decade $^{-1}$ from 1984 to 2003 over the Arabian Sea (Zhao et al., 2008), $+0.0063 \pm 0.0040 \mathrm{yr}^{-1}$ from 1997 to 2010 over northern India (Hsu et al., 2012), and significant increases in $\mathrm{SO}_{2}$ and black carbon emission from 1980 to 2009 over southern Asia (Street et al., 2006; Mian Chin et al., 2013). The recent rapid economic growth in India, where GDP increased (World Bank Group, 2014) by $7.5 \%$ annually from 1998 to 2010, coupled with the second largest and growing population of the world, can contribute to the significant enhancement in the release of aerosol and its precursors (Ramanathan et al., 2007a, b; Lawrence and Lelieveld, 2010).

Regions 5-7 in China show markedly increasing AOT. The Chinese economy is the second largest in the world (GDP of approximately USD 7.3 trillion in 2011; World Bank Group, 2014) and had annual growth rates (World Bank Group, 2014) of $\sim 10 \%$ or more over the past decade. Moreover, China is the world's most populous country, with a growing population of more than 1.35 billion people. As a consequence of the growth of industry, related construction, and changes in land usage, large amounts of aerosols and their precursors are emitted into the atmosphere (Smith et al., 2001, 2003; Zhao et al., 2008; Yoon et al., 2012) in the conurbations of China. Additionally, increasing amounts of mineral dust from Asian deserts are transported by the predominantly westerly winds in spring and summer into this region, prior to its transport and deposition into the Pacific (Zhang et al., 2003; Yoon et al., 2012). Except for the decrease in MODIS-Terra AOT over central China, a significant increase prevails over all regions of China $\left(+2.26 \pm 1.71\right.$ to $+2.97 \pm 2.30 \% \mathrm{yr}^{-1}$ for MODISTerra, $+2.43 \pm 1.94$ to $+3.39 \pm 2.53 \% \mathrm{yr}^{-1}$ for MISRTerra, $+1.45 \pm 1.05$ to $+2.85 \pm 1.99 \% \mathrm{yr}^{-1}$ for SeaWiFSOrbView- 2 , and $+4.05 \pm 3.66$ to $+5.66 \pm 4.14 \% \mathrm{yr}^{-1}$ for MODIS-Aqua AOT). Similarly, a positive tendency has been reported in various studies, e.g., $+17.3 \pm 6.7 \% \mathrm{decade}^{-1}$ of TOMS AOT from 1979 to 1998 for the coastal plain of China from (Massie et al., 2004), $+0.0031 \pm 0.0036 \mathrm{yr}^{-1}$ of SeaWiFS AOT from 1997 to 2010 (Hsu et al., 2012), +15 to $+52 \%$ of MISR and AERONET AOTs from 2000 to 2009 (de Meij et al., 2012), and +4.59 to $+6.26 \% \mathrm{yr}^{-1}$ from 2003 to 2007 at the Beijing AERONET station (Yoon et al., 2012).

The AOT trend over region 8 (Korea and Japan), located in the same belt of westerly winds (Yoon et al., 2007; Kim et al., 2007; Lee et al., 2010), shows a consistent increase $\left(+0.66 \pm 0.50 \% \mathrm{yr}^{-1}\right.$ for MODIS-Terra, $+4.16 \pm 3.30 \% \mathrm{yr}^{-1}$ for MISR-Terra, $+2.40 \pm 1.76 \% \mathrm{yr}^{-1}$ for SeaWiFS-OrbView-2 AOT, and $+0.51 \pm 0.41 \% \mathrm{yr}^{-1}$ for MODIS-Aqua), which is slightly less pronounced than over China. Although a decrease in local industrial emissions of sulfur dioxide $\left(\mathrm{SO}_{2}\right)$ from 1999 to 2007, Ohara et al., 2007; Lu et al., 2010) and significantly decreasing tropospheric nitrogen dioxide $\left(\mathrm{NO}_{2}\right)$ amounts from 1996 to 2011 have been reported (Hilboll et al., 2013), this behavior can be attributed to the increasing desertification around Asian deserts (Jeong et al., 2011). This hypothesis is supported by the results of previous studies, +0.01 decade $^{-1}$ of AVHRR AOT from 

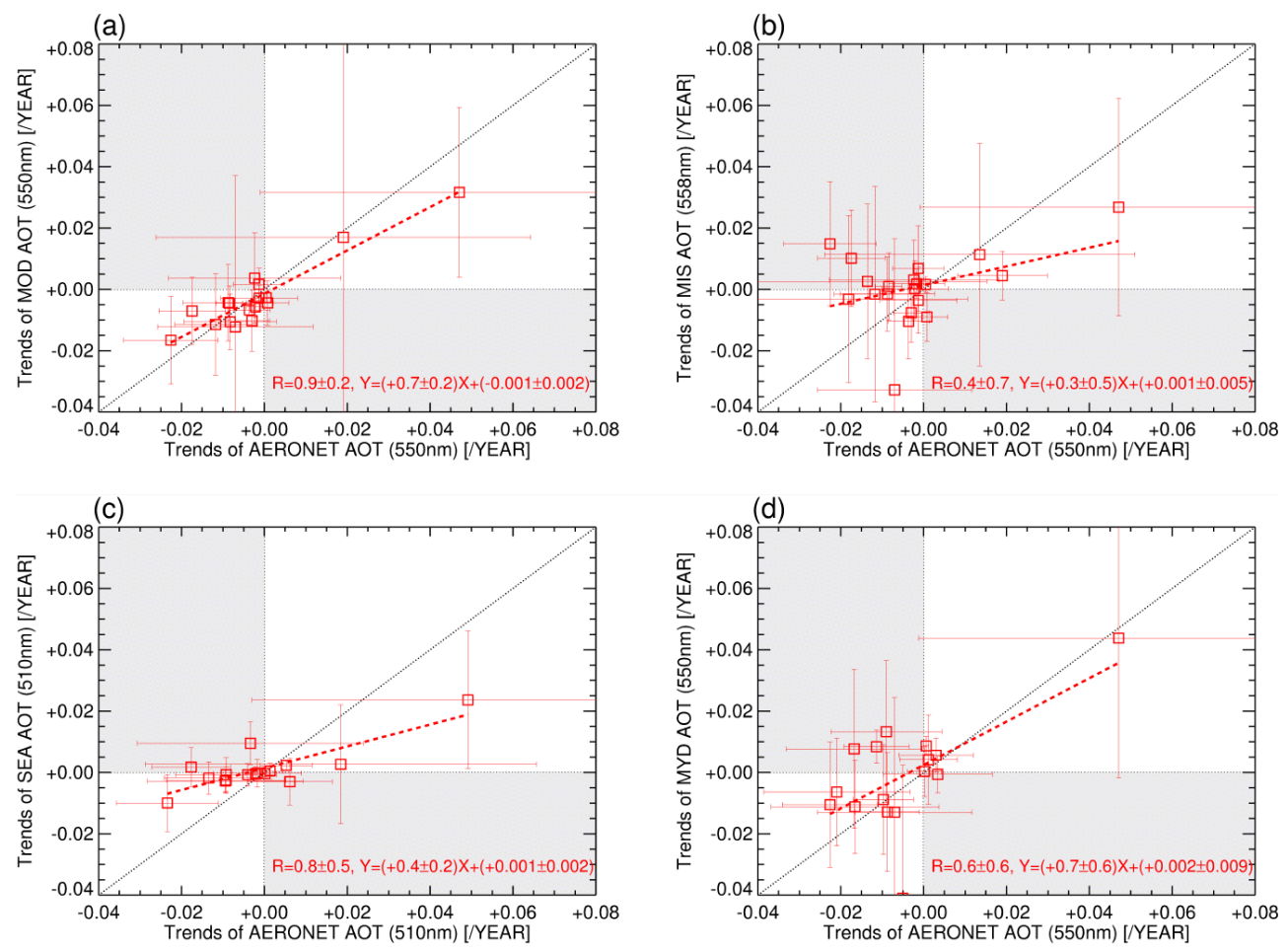

Figure 8. Scatter plots of comparison between the weighted trends of AERONET and (a) MODIS (Terra), (b) MISR (Terra), (c) SeaWiFS (OrbView-2), and (d) MODIS (Aqua) AOTs.

1984 to 2003 over the East China Sea and Yellow Sea (Zhao et al., 2008), and +0.58 to $+1.84 \% \mathrm{yr}^{-1}$ for coarse-mode dominant AOT from 2003 to 2009 at the Shirahama station in Japan (Yoon et al., 2012).

In the western USA (region 9), the increasing trend observed by MODIS (Aqua) from 2003 to 2008 $\left(+5.59 \pm 0.41 \% \mathrm{yr}^{-1}\right)$ apparently disagrees with the trends derived from the other instruments $\left(-1.36 \pm 0.90 \% \mathrm{yr}^{-1}\right.$ for MODIS-Terra, $-0.30 \pm 0.24 \% \mathrm{yr}^{-1}$ for MISR-Terra, and $-0.77 \pm 0.56 \% \mathrm{yr}^{-1}$ for SeaWiFS-OrbView-2 AOT). The low rainfall and resultant enhanced fire activity (see Fig. 12) which occurred over parts of the western USA from 2003 to 2008 (La Niña phases) (Westerling et al., 2006) could be the cause of the significant difference between the trend estimates. Furthermore, although the fire activity generally lasts for several days, as wildfires typically ignite in the afternoon (Mu et al., 2011), the increase resulting from the fires might be much more significant in MODIS (Aqua) AOT, which flies in a Sun-synchronous orbit with an early afternoon Equator-crossing time. Collaud Coen et al. (2013) reported a significant positive trend of the aerosol scattering coefficient (i.e., $21.66 \%$ increase from 2001 to 2010) at the station on Mt. Zirkel Wilderness, Colorado, western USA.

Over the eastern USA (region 10), a decreasing AOT trend is generally observed $\left(-5.21 \pm 3.47 \% \mathrm{yr}^{-1}\right.$ for MODIS-Terra, $-2.87 \pm 2.14 \% \mathrm{yr}^{-1}$ for MISR-Terra, and $-0.86 \pm 0.63 \% \mathrm{yr}^{-1}$ for SeaWiFS-OrbView-2 AOT). This trend has been consistently reported in many studies, e.g., -0.02 decade $^{-1}$ of AVHRR AOT from 1984 to 2003 over the North Atlantic Ocean close to the eastern USA (Zhao et al., 2008); $-0.0028 \pm 0.0010 \mathrm{yr}^{-1}$ of SeaWiFS AOT from 1997 to 2010 over the eastern USA (Hsu et al., 2012); 40.5 to $85.3 \%$ decrease from 2001 to 2010 at station Shenandoah NP, Virginia, eastern USA (Collaud Coen et al., 2013); and -0.34 to $-0.67 \% \mathrm{yr}^{-1}$ from 2003 to 2007 at GSFC AERONET stations (Yoon et al., 2012). As reported in previous studies (Streets et al., 2003; Zhao et al., 2008; Yoon et al., 2012), this behavior can be attributed in large part to the results of legislation and the subsequent measures introduced to reduce pollutant emissions. The increasing trend of MODIS (Aqua) AOT in the afternoon (i.e., $+1.16 \pm 0.85 \% \mathrm{yr}^{-1}$ ) is different to the other derived trends. However, it should be noted that the MODIS (Aqua) trends over the eastern USA are not significant in most areas, and were contributed by the significant trends over the central USA, as shown in Figs. 9d and 10d.

To investigate further the remarkable behavior of AOTs over eastern China (region 6), where the largest aerosol loadings are observed, the time series of atmospheric AOTs normalized to means, tropospheric $\mathrm{NO}_{2}$ and $\mathrm{SO}_{2}$ columns from SCIAMACHY (Burrows et al., 1995; Richter et al., 2005; Bovensmann et al., 1999; Hilboll et al., 2013), and Chinese GDP (World Bank Group, 2014) are compared in Fig. 13 from 2003 to 2008. This period is chosen because almost all 
(a) MODIS (TERRA)

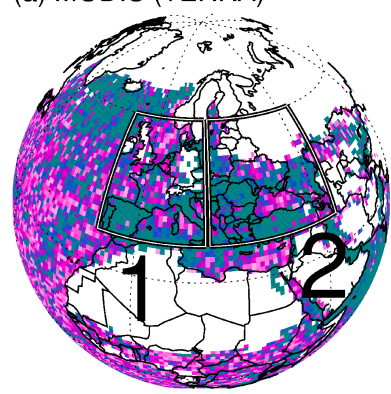

(b) MISR (TERRA)

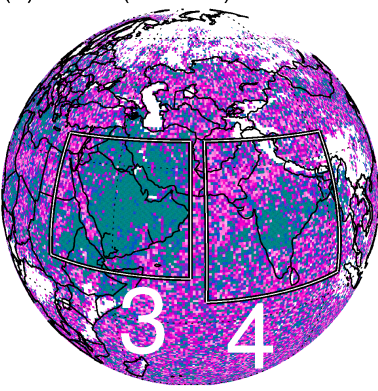

(c) SeaWiFS (OrbView-2)

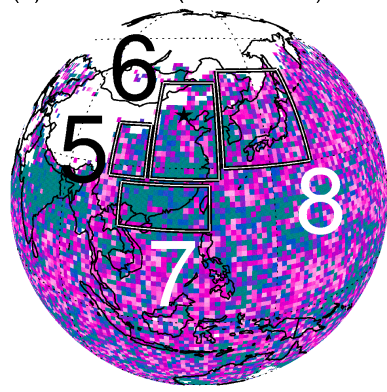

(d) MODIS (AQUA)

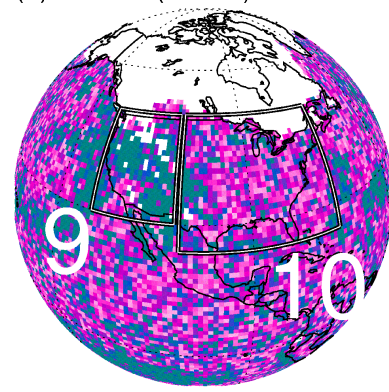

$\square$ No observation or not enough data

Significance of weighted trend

\begin{tabular}{lllllllll}
\hline & & & & & & & & \\
0.00 & 0.25 & 0.50 & 0.75 & 1.00 & 1.25 & 1.50 & 1.75 & 2.00
\end{tabular}

Figure 9. Plots of the significance of weighted trends derived from (a) MODIS (Terra) AOT (550 nm), (b) MISR (Terra) AOT $(558 \mathrm{~nm})$, (c) SeaWiFS (OrbView-2) AOT $(510 \mathrm{~nm})$, and (d) MODIS (Aqua) AOT $(550 \mathrm{~nm})$. The significance is defined as $\left|B_{\mathrm{g}} / \sigma_{B_{\mathrm{g}}}\right|$, where $B_{\mathrm{g}}$ and $\sigma_{B_{\mathrm{g}}}$ are the weighted trend and its standard deviation. A significance larger than 2 means that the trend is statistically significant within a $95 \%$ confidence level.

data sets are available. As shown in Veefkind et al. (2011), the spatial distribution of aerosol and short-lived trace gases (i.e., $\mathrm{NO}_{2}$ and $\mathrm{SO}_{2}$ ) over China are similar and highly correlated because they are generated from a common anthropogenic source (Yoon et al., 2012; Zhang et al., 2003). Therefore, a similar behavior of these aerosols and trace gases is expected when the influence of wind-blown mineral dust from Asian deserts is minimal. In spite of having different temporal samplings and retrieval algorithms, the relative behaviors of the AOTs retrieved from the set of satellite instruments are all in reasonable agreement with each other and the ground-based observations, e.g., the AERONET AOTs measured in Beijing. The AOT trends over eastern China in spring, summer, autumn, and winter are up to $+2.53,+3.25$, +3.26 , and $+3.58 \% \mathrm{yr}^{-1}$ from 2003 to 2008 , respectively.

The atmospheric oxidation of $\mathrm{SO}_{2}$ produces sulfuric acid, $\mathrm{H}_{2} \mathrm{SO}_{4}$, which has low volatility but is highly hygroscopic, and thus an ideal cloud condensation nucleus (Wallace and Hobbs, 2006). Additionally, $\mathrm{SO}_{2}$ in the atmosphere reflects the amount and type of fossil fuel combustion (Veefkind et
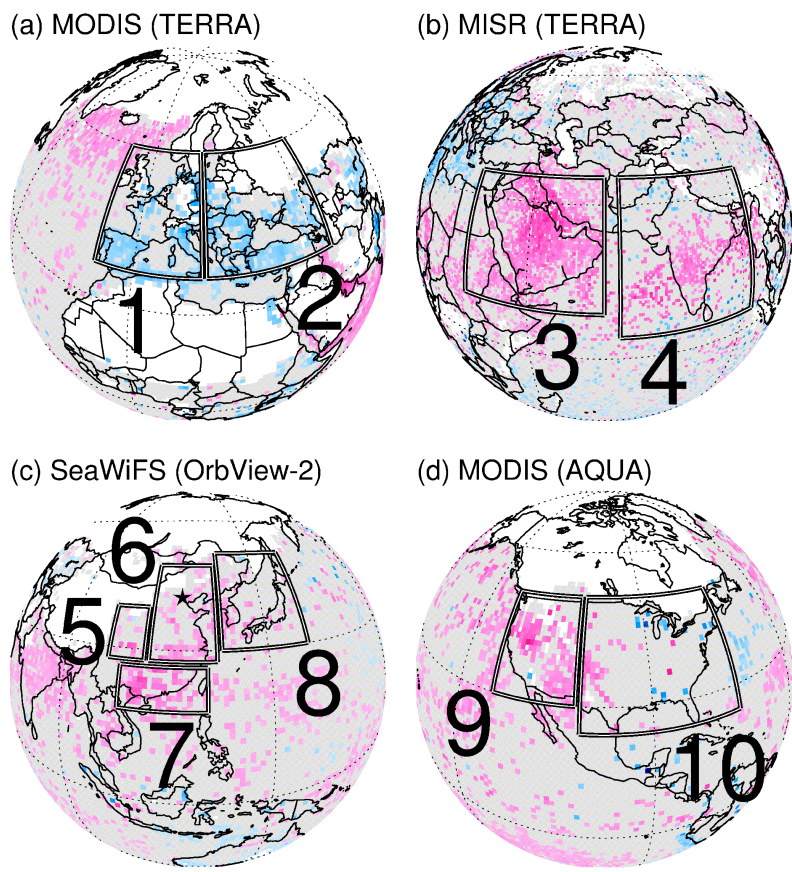

(d) MODIS (AQUA)

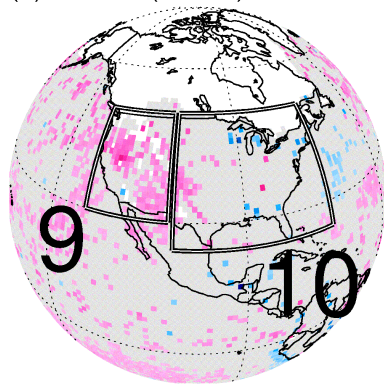

$\square$ No observation or not enough data $\quad \square$ No significant trend Weighted trends of AOT $\left[\times 10^{-2} \mathrm{yr}^{-1}\right]$

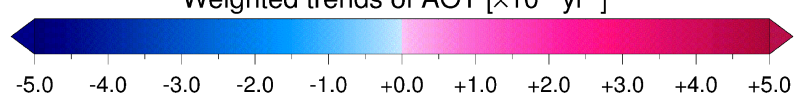

Figure 10. Weighted trends derived from satellite-retrieved AOTs for the selected regions. Each spaceborne instrument has a different local sampling time; the equatorial crossing times for the satellites are 10:30 for Terra (descending node), 12:20 for OrbView-2 (descending node), and 13:30 for Aqua (ascending node). Weighted trends $\left(B_{\mathrm{g}}\right)$ for each grid with significance $\left(\left|B_{\mathrm{g}} / \sigma_{B_{\mathrm{g}}}\right|\right)$ less than 2 are shown in grey, representing nonsignificant trends.

al., 2011). As shown in Fig. 14, SCIAMACHY $\mathrm{SO}_{2}$ over eastern China is temporally correlated with AERONET finemode dominant AOT (i.e., correlation coefficient $R=0.6$ ) (Yoon et al., 2012) at Beijing in winter, when mineral dust from Asian deserts is low. Therefore, the AOT trend in winter over eastern China can be partly attributed to change of secondary gas-transformed aerosol due to industrial growth. Winter trends of $+22.41 \% \mathrm{yr}^{-1}$ for fine-mode dominant aerosols in Beijing and $+9.32 \% \mathrm{yr}^{-1}$ for $\mathrm{SO}_{2}$ over eastern China from 2003 to 2008 are obtained.

The maximum aerosol loading over China occurs in spring and early summer (i.e., dry and windy seasons), when mineral dust is transported by westerly winds from the Asian deserts (Yoon et al., 2007, 2012; Kim et al., 2007; Lee et al., 2010). The MISR AOTs over the Asian deserts are strongly correlated with the other three independent AOTs over eastern Asia (i.e., the correlation ranges from 0.8 to 0.9 , as shown in Fig. 15). A significant increase of atmospheric aerosol in spring is observed in all data sets, which varies from +0.94 to $+2.53 \% \mathrm{yr}^{-1}$. This can be attributed to the growth 


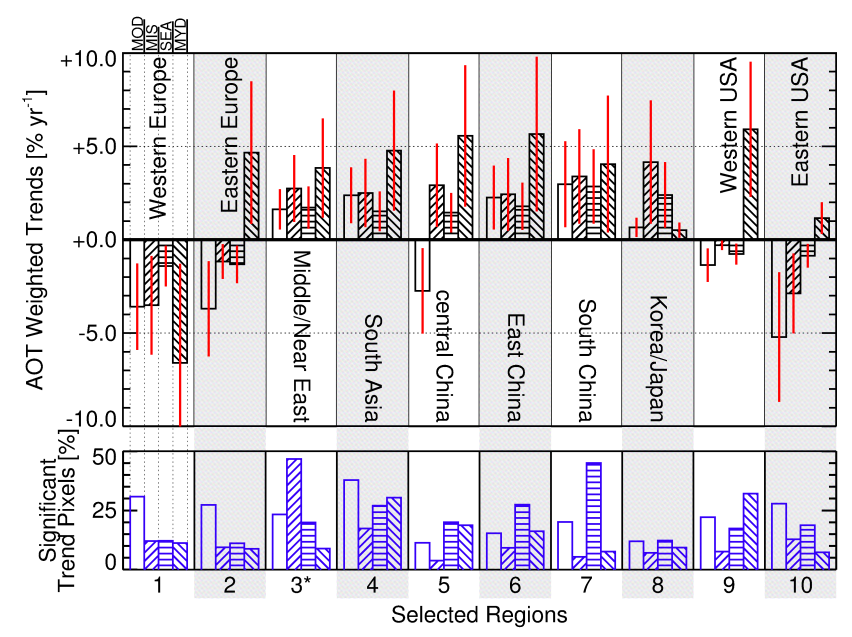

Figure 11. The relative regional trends and standard deviations $( \pm 2 \sigma)$ of the four AOT data products, retrieved from the measurements made by MODIS-Terra (MOD) from March 2001 to December 2009, MISR-Terra (MIS) from March 2001 to December 2010, SeaWiFS-OrbView-2 (SEA) from January 1998 to December 2007, and MODIS-Aqua (MYD) from January 2003 to December 2008, for the regions defined in Figs. 1, 9, and 10. The regional trends are the mean of the weighted trends that are significant within a $95 \%$ confidence level. The blue bar chart below shows the percentage of pixels showing a significant trend for the selected regions. For region 3 (Middle/Near East), only MISR AOTs are available over both land and ocean as a result of the bright surface saturating the measurements made by the other instruments.

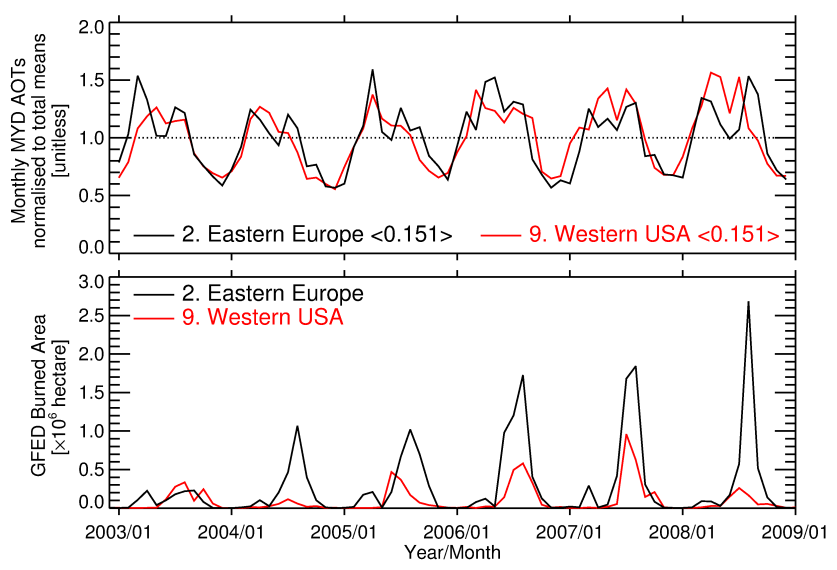

Figure 12. Plots of the time series of atmospheric AOTs normalized to their average mean values from MODIS-Aqua (MYD) data set (top) and Global Fire Emissions Database (GFED) burned area (bottom) over eastern Europe (region 2, black) and the western USA (region 9, red) from 2003 to 2008.

of Asian deserts (Jeong et al., 2011) and thus the increasing occurrence of desert dust aerosols accompanied by reduced precipitation (approximately $-5.62 \% \mathrm{yr}^{-1}$ estimated from NCEP/NCAR reanalysis data (NOAA Earth System Research Laboratory, 2014)).

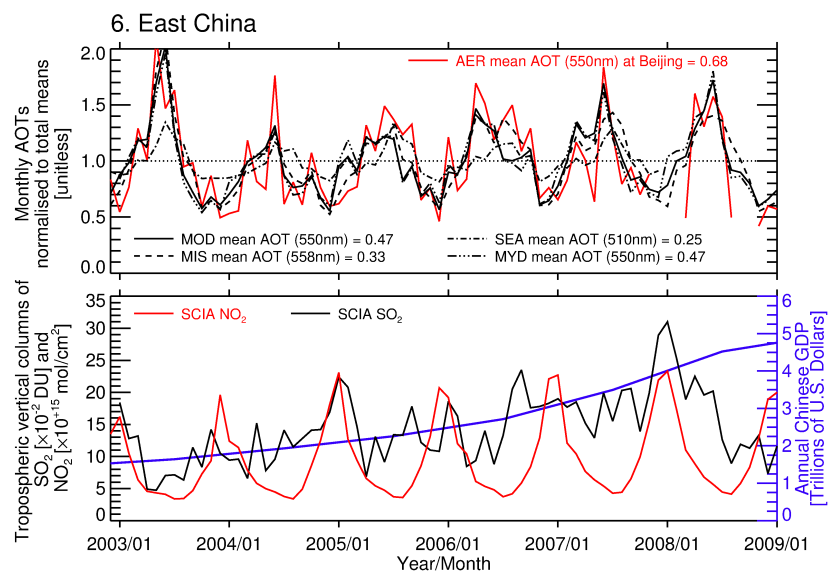

Figure 13. Time series of atmospheric AOTs normalized to their average mean values from the MODIS-Terra (MOD), MISR-Terra (MIS), SeaWiFS-OrbView-2 (SEA), MODIS-Aqua (MYD), and AERONET (AER) data sets; tropospheric nitrogen dioxide and sulfur dioxide columns from SCIAMACHY (SCIA) over eastern China (region 6); and Chinese GDP from 2003 to 2008.

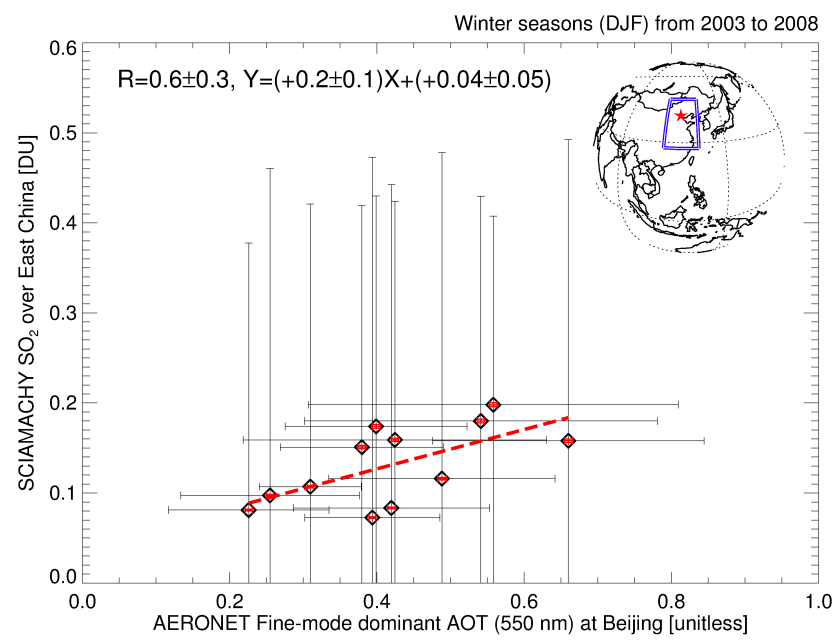

Figure 14. Plot of the correlation between AERONET fine-mode dominant AOT at Beijing and SCIAMACHY tropospheric $\mathrm{SO}_{2}$ in winter seasons from 2003 to 2008. Black and red error bars show natural variability and standard retrieval error within a $95 \%$ confidence level, respectively. Some AERONET fine-mode dominant data are not available in some winter months due to insufficient number of observations per month (Yoon et al., 2012).

\section{Conclusions and outlook}

By using a new trend model (i.e., weighted least-squares regression) and independent measurements (i.e., MODISTerra, MISR-Terra, SeaWiFS-OrbView-2, and MODIS-Aqua observations) from 1998 to 2010, we have estimated the temporal change of AOT in the selected regions. The uncertainty caused by the limited/different temporal sampling of polar-orbiting satellites has been identified using real-time 

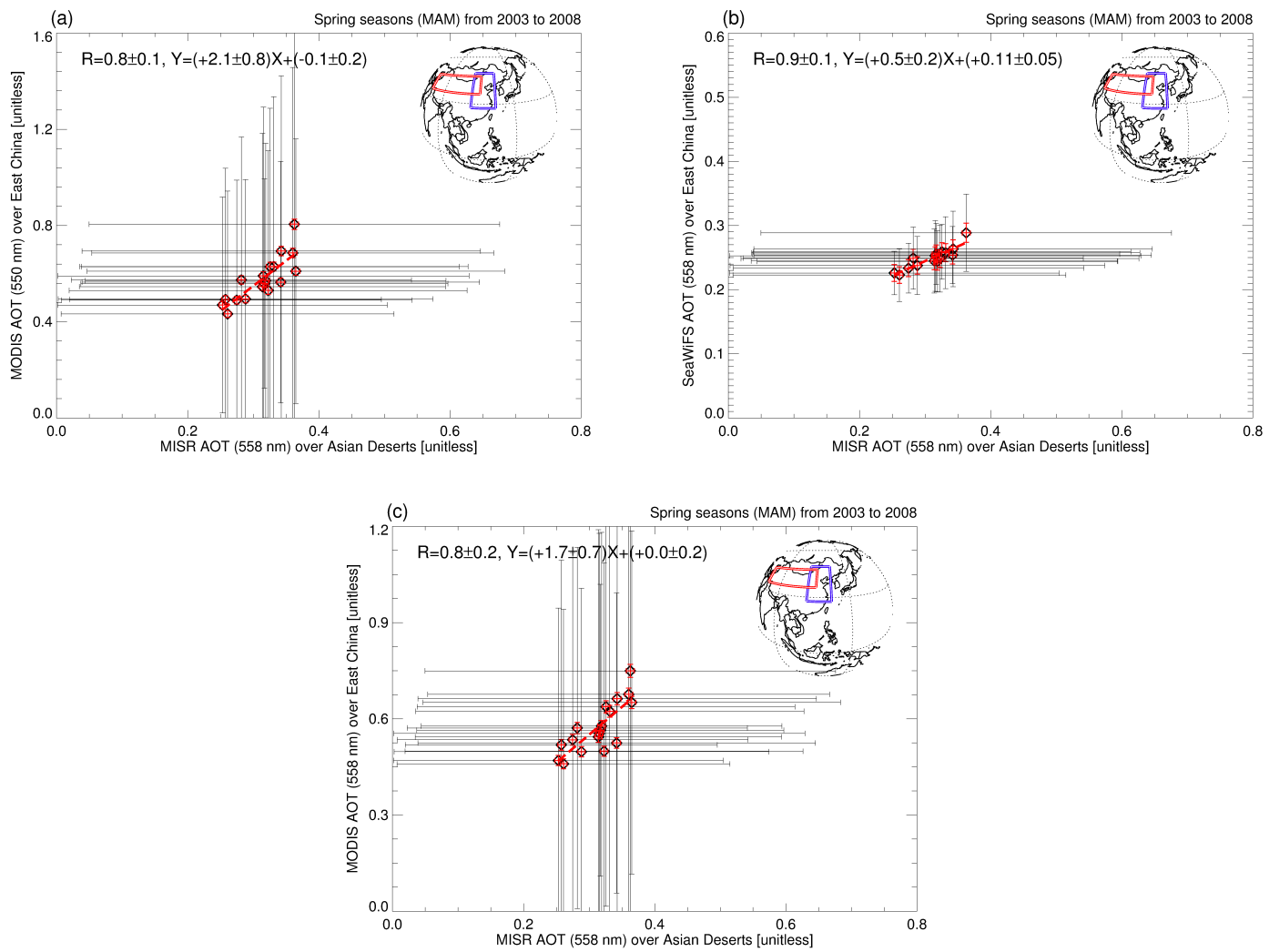

Figure 15. Plots of the correlations between MISR (Terra) AOT over Asian deserts and (a) MODIS (Terra), (b) SeaWiFS (OrbView-2), and (c) MODIS (Aqua) AOTs over eastern China in spring seasons from 2003 to 2008. Black and red error bars show natural variability and standard retrieval error within a $95 \%$ confidence level, respectively.

AERONET AOT. It is an inevitable bias in the trend estimates of the "ideal" polar-orbiting satellite observation to the "actual trend". Another uncertainty factor discussed in this study was cloud occurrence, which prevents the retrieval of cloud-free AOT using passive visible sensors, and therefore influences the calculation of monthly means with statistical representativeness. This study presented an approach to minimize this effect by use of a weighted least-squares regression, and showed the significant improvements in the trend estimates around Brazil, India, southern Africa, and southeastern Asia, where cloud cover is common. The trends have been validated with the corresponding AOT trends at the available AERONET stations. Significant decreases in AOT over western Europe and the eastern USA, as well as increases over the Near/Middle East, southern Asia, and eastern Asia, were observed. In particular, the dramatic increases in AOT over the region of eastern China, associated with rapid industrial growth and desertification, were discussed in this study. The recent severe smog episode in China during winter 2012/13 and 2013/14 could be a dramatic consequence of the emissions resulting from economic growth, coupled with minimal environmental legislation.
Acknowledgements. The authors would like to thank NASA and NOAA ESRL teams for providing AERONET, MODIS, MISR AOT data, SeaWiFS upwelling reflectance, and NCEP/NCAR reanalysis data. This work was supported in part by the CityZen project (megacity - Zoom for the Environment: EU Seventh Framework Programme of the European Commission), the DFG project Terra, and the state and University of Bremen.

Edited by: M. Kanakidou

\section{References}

Arola, A., Eck, T. F., Huttunen, J., Lehtinen, K. E. J., Lindfors, A. V., Myhre, G., Smirnov, A., Tripathi, S. N., and Yu, H.: Influence of observed diurnal cycles of aerosol optical depth on aerosol direct radiative effect, Atmos. Chem. Phys., 13, 78957901, doi:10.5194/acp-13-7895-2013, 2013.

Barnaba, F., Angelini, F., Curci, G., and Gobbi, G. P.: An important fingerprint of wildfires on the European aerosol load, Atmos. Chem. Phys., 11, 10487-10501, doi:10.5194/acp-1110487-2011, 2011.

Barnes, R. A., Eplee Jr., R. E., Schmidt, G. M., Patt, F. S., and McClain, C. R.: Calibration of SeaWiFS, I: Direct techniques, Appl. Optics, 40, 6682-6700, doi:10.1364/AO.40.006682, 2001. 
Basart, S., Pérez, C., Cuevas, E., Baldasano, J. M., and Gobbi, G. P.: Aerosol characterization in Northern Africa, Northeastern Atlantic, Mediterranean Basin and Middle East from direct-sun AERONET observations, Atmos. Chem. Phys., 9, 8265-8282, doi:10.5194/acp-9-8265-2009, 2009.

Bovchaliuk, A., Milinevsky, G., Danylevsky, V., Goloub, P., Dubovik, O., Holdak, A., Ducos, F., and Sosonkin, M.: Variability of aerosol properties over Eastern Europe observed from ground and satellites in the period from 2003 to 2011, Atmos. Chem. Phys., 13, 6587-6602, doi:10.5194/acp-13-6587-2013, 2013.

Bovensmann, H., Burrows, J. P., Buchwitz, M., Frerick, J., Noël, S., Rozanov, V. V., Chance, K. V., and Goede, A. P. H.: SCIAMACHY - Mission Objectives and Measurement Modes, J. Atmos. Sci., 56, 127-150, doi:10.1175/15200469(1999)056<0127:SMOAMM>2.0.CO;2, 1999.

Burrows, J. P., Hölzle, E., Goede, A. P. H., Visser, H., and Fricke, W.: SCIAMACHY - Scanning Imaging Absorption Spectrometer for Atmospheric Chartography, Acta Astronaut., 35, 445-451, 1995.

Bruegge, C. J., Diner, D. J., Kahn, R. A., Chrien, N., Helmlinger, M. C., Gaitley, B. J., and Abdou, W. A.: The MISR radiometric calibration process, Remote Sens. Environ., 107, 2-11, doi:10.1016/j.rse.2006.07.024, 2007.

Chubarova, N. Y., Sviridenkov, M. A., Smirnov, A., and Holben, B. N.: Assessments of urban aerosol pollution in Moscow and its radiative effects, Atmos. Meas. Tech., 4, 367-378, doi:10.5194/amt-4-367-2011, 2011.

Chubarova, N., Nezval', Ye., Sviridenkov, I., Smirnov, A., and Slutsker, I.: Smoke aerosol and its radiative effects during extreme fire event over Central Russia in summer 2010, Atmos. Meas. Tech., 5, 557-568, doi:10.5194/amt-5-557-2012, 2012.

Climate and Clean Air Coalition (CCAC): Short-lived climate pollutants, available at: http://www.unep.org/ccac/ ShortLivedClimatePollutants/tabid/101650/Default.aspx (last access: June 2013), 2012.

Davidson, E. A. and Artaxo, P.: Globally significant changes in biological processes of the Amazon Basin: Results of the Largescale Biosphere-Atmosphere Experiment, Global Change Biol., 10, 1-11, doi:10.1111/j.1529-8817.2003.00779.x, 2004.

de Meij, A., Pozzer, A., and Lelieveld, J.: Trend analysis in aerosol optical depths and pollutant emission estimates between 2000 and 2009, Atmos. Environ., 51, 75-85, doi:10.1016/j.atmosenv.2012.01.059, 2012.

de Ruyter de Wildt, M., Eskes, H., and Boersma, K. F.: The global economic cycle and satellite-derived $\mathrm{NO}_{2}$ trends over shipping lanes, Geophys. Res. Lett., 39, L01802, doi:10.1029/2011GL049541, 2012.

Dey, S., Tripathi, S. N., Singh, R. P., and Holben, B. N.: Influence of dust storms on the aerosol optical properties over the Indo-Gangetic plains, J. Geophys. Res., 109, D20211, doi:10.1029/2004JD004924, 2004.

Di Girolamo, L., Menzies, A., Zhao, G., Mueller, K., Moroney, C., and Diner, D. J. : Level 3 cloud fraction by altitude algorithm theoretical basis, Rep. JPL D-62358, Jet Propul. Lab., Pasadena, Calif., available at: http://eospso.gsfc.nasa.gov/eos_homepage/ for_scientists/atbd/docs/MISR/MISR_CFBA_ATBD.pdf, last access: June 2014.
Dubovik, O., Holben, B. N., Eck, T. F., Smirnov, A., Kaufman, Y. J., King, M. D., Tanré, D., and Slutsker, I.: Variability of absorption and optical properties of key aerosol types observed in worldwide locations, J. Atmos. Sci., 59, 590-608, doi:10.1175/15200469(2002)059<0590:VOAAOP>2.0.CO;2, 2002.

Eck, T. F., Holben, B. N., Reid, J. S., Dubovik, O., Smirnov, A., O'Neill, N. T., Slutsker, I., and Kinne, S.: Wavelength dependence of the optical depth of biomass burning, urban, and desert dust aerosol, J. Geophys. Res., 104, 31333-31349, doi:10.1029/1999JD900923, 1999.

Eplee Jr., R. E., Robinson, W. D., Bailey, S. W., Clark, D. K., Werdell, P. J., Wang, M., Barnes, R. A., and McClain, C. R.: The calibration of SeaWiFS, Part 2: Vicarious techniques, Appl. Optics, 40, 6701-6718, doi:10.1364/AO.40.006701, 2001.

Franke, K., Richter, A., Bovensmann, H., Eyring, V., Jöckel, P., Hoor, P., and Burrows, J. P.: Ship emitted $\mathrm{NO}_{2}$ in the Indian Ocean: comparison of model results with satellite data, Atmos. Chem. Phys., 9, 7289-7301, doi:10.5194/acp-9-7289-2009, 2009.

Giglio, L., Randerson, J. T., van der Werf, G. R., Kasibhatla, P. S., Collatz, G. J., Morton, D. C., and DeFries, R. S.: Assessing variability and long-term trends in burned area by merging multiple satellite fire products, Biogeosciences, 7, 1171-1186, doi:10.5194/bg-7-1171-2010, 2010.

Giles, D. M., Holben, B. N., Eck, T. F., Sinyuk, A., Smirnov, A., Slutsker, I., Dickerson, R. R., Thompson, A. M., and Schafer, J. S.: An analysis of AERONET aerosol absorption properties and classifications representative of aerosol source regions, J. Geophys. Res., 117, D17203, doi:10.1029/2012JD018127, 2012.

Goddard Space Flight Center - NASA: SeaWiFS Project, http: //oceancolor.gsfc.nasa.gov/SeaWiFS, last access: June 2014.

Goldman Sachs: Goldman Sachs, Dreaming With BRICs: The Path to 2050, Global Economics Paper No: 99, 2003.

Gordon, H. R.: In-orbit calibration strategy for ocean color sensors, Remote Sens. Environ., 63, 265-278, 1998.

Grubbs, F.: Procedures for Detecting Outlying Observations in Samples, Technometrics, 11, 1-21, 1969.

Hatzianastassiou, N., Gkikas, A., Mihalopoulos, N., Torres, O., and Katsoulis, B. D.: Natural versus anthropogenic aerosols in the eastern Mediterranean basin derived from multiyear TOMS and MODIS satellite data, J. Geophys. Res., 114, D24202, doi:10.1029/2009JD011982, 2009.

Hayn, M., Beirle, S., Hamprecht, F. A., Platt, U., Menze, B. H., and Wagner, T.: Analysing spatio-temporal patterns of the global $\mathrm{NO}_{2}$-distribution retrieved from GOME satellite observations using a generalized additive model, Atmos. Chem. Phys., 9, 64596477, doi:10.5194/acp-9-6459-2009, 2009.

Herman, J. R., Bhartia, P. K., Torres, O., Hsu, C., Seftor, C., and Celarier, E.: Global distribution of UV absorbing aerosols from Nimbus 7/TOMS data, J. Geophys. Res., 102, 16911-16922, doi:10.1029/96JD03680, 1997.

Hilboll, A., Richter, A., and Burrows, J. P.: Long-term changes of tropospheric $\mathrm{NO}_{2}$ over megacities derived from multiple satellite instruments, Atmos. Chem. Phys., 13, 4145-4169, doi:10.5194/acp-13-4145-2013, 2013.

Holben, B. N., Eck, T. F., Slutsker, I., Tanré,v, Buis, J. P., Setzer, A., Vermote, E., Reagan, J. A., Kaufman, Y., Nakajima, T., Lavenu, F., Jankowiak, I., and Smirnov, A.: AERONET - A federated instrument network and data archive 
for aerosol characteristics, Remote Sens. Environ., 66, 1-16, doi:10.1016/S0034-4257(98)00031-5, 1998.

Holben, B. N., Tanré, D., Smirnov, A., Eck, T. F., Slutsker, I., Abuhassan, N., Newcomb, W. W., Schafer, J. S., Chatenet, B., Lavenu, F., Kaufman, Y. J., Vande Castle, J., Setzer, A., Markham, B., Clark, D., Frouin, R., Halthore, R., Karneli, A., O’Neill, N. T., Pietras, C., Pinker, R. T., Voss, K., and Zibordi, G.: An emerging ground-based aerosol climatology: Aerosol optical depth from AERONET, J. Geophys. Res., 106, 1206712097, doi:10.1029/2001JD900014, 2001.

Hsu, N. C., Gautam, R., Sayer, A. M., Bettenhausen, C., Li, C., Jeong, M. J., Tsay, S.-C., and Holben, B. N.: Global and regional trends of aerosol optical depth over land and ocean using SeaWiFS measurements from 1997 to 2010, Atmos. Chem. Phys., 12, 8037-8053, doi:10.5194/acp-12-8037-2012, 2012.

Hyer, E. J., Reid, J. S., and Zhang, J.: An over-land aerosol optical depth data set for data assimilation by filtering, correction, and aggregation of MODIS Collection 5 optical depth retrievals, Atmos. Meas. Tech., 4, 379-408, doi:10.5194/amt-4-379-2011, 2011.

Ignatov, A., Minnis, P., Loeb, N., Wielicki, B., Miller, W., SunMack, S., Tanré, S., Remer, L., Laszlo, I., and Geier, E.: Two MODIS Aerosol Products over Ocean on the Terra and Aqua CERES SSF Datasets, J. Atmos. Sci., 62, 1008-1031, doi:10.1175/JAS3383.1, 2005.

Jeong, S.-J., Ho, C.-H., Brown, M. E., Kug, J.-S., and Piao, S.: Browning in desert boundaries in Asia in recent decades, J. Geophys. Res., 116, D02103, doi:10.1029/2010JD014633, 2011.

Jet Propulsion Laboratory - NASA: MISR Multiangle Imaging SpectroRadiometer, http://www-misr.jpl.nasa.gov, last access: June 2014.

Kahn, R. A., Li, W.-H., Martonchik, J., Bruegge, C., Diner, D., Gaitley, B., Abdou, W., Dubovik, O., Holben, B., Smirnov, S., Jin, Z., and Clark, D.: MISR low-light-level calibration, and implications for aerosol retrieval over dark water, J. Atmos. Sci., 62, 1032-1062, doi:10.1175/JAS3390.1, 2005a.

Kahn, R. A., Gaitley, B., Martonchik, J., Diner, D., Crean, K., and Holben, B.: MISR global aerosol optical depth validation based on two years of coincident AERONET observations, J. Geophys. Res., 110, D10S04, doi:10.1029/2004JD004706, 2005 b.

Kahn, R. A., Garay, M., Nelson, D., Yau, K., Bull, M., and Martonchik, J.: Satellite-derived aerosol optical depth over dark water from MISR and MODIS: Comparisons with AERONET and implications for climatological studies, J. Geophys. Res., 112, D18205, doi:10.1029/2006JD008175, 2007.

Kahn, R. A., Gaitley, B. J., Garay, M. J., Diner, D. J., Eck, T. F., Smirnov, A., and Holben, B. N.: Multiangle Imaging SpectroRadiometer global aerosol product assessment by comparison with the Aerosol Robotic Network, J. Geophys. Res., 25, D23209, doi:10.1029/2010JD014601, 2010.

Kanakidou, M., Mihalopoulos, N., Kindap, T., Im, U., Vrekoussis, M., Gerasopoulos, E., Dermitzaki, E., Unal, A., Kocak, M., Markakis, K., Melas, D., Kouvarakis, G., Youssef, A. F., Richter, A., Hatzianastassiou, N., Hilboll, A., Ebojie, F., von Savigny, C., Ladstaetter-Weissenmayer, A., Burrows, J., and Moubasher, H.: Megacities as hot spots of air pollution in the East Mediterranean, Atmos. Environ., 45, 1223-1235, doi:10.1016/j.atmosenv.2010.11.048, 2011.
Karnieli, A., Derimian, Y., Indoitu, R., Panov, N., Levy, R. C., Remer, L. A., Maenhaut, W., and Holben, B. N.: Temporal trend in anthropogenic sulfur aerosol transport from central and eastern Europe to Israel, J. Geophys. Res., 114, D00D19, doi:10.1029/2009JD011870, 2009.

Kaufman, Y. J., Tanré, D., Remer, L. A., Vermote, E. F., Chu, A., and Holben, B. N.: Operational remote sensing of tropospheric aerosol over land from EOS moderate resolution imaging spectroradiometer, J. Geophys. Res., 102, 17051-17068, 1997.

Kim, J., Lee, J., Lee, H. C., Higurashi, A., Takemura, T., and Song, C. H.: Consistency of the aerosol type classification from satellite remote sensing during the Atmospheric Brown Cloud-East Asia Regional Experiment campaign, J. Geophys. Res., 112, D22S33, doi:10.1029/2006jd008201, 2007.

Kim, M., Kim, J., Wong, M. S., Yoon, J., Lee, J., Wu, D., Chan, P.W., Nichol, J. E., Chung, C.-Y., and Ou, M.-L.: Improvement of aerosol optical depth retrieval over Hong Kong from a geostationary meteorological satellite using critical reflectance with background optical depth correction, Remote Sens. Environ., 142, 176-187, doi:10.1016/j.rse.2013.12.003, 2014.

Kirby, K. R., Laurance, W. F., Albernaz, A. K., Schroth, G., Fearnside, P. M., Bergen, S., Venticinque, E. M., and da Costa, C.: The future of deforestation in the Brazilian Amazon, Futures, 38, 432-453, doi:10.1016/j.futures.2005.07.011, 2006.

Kocha, C., Tulet, P., Lafore, J.-P., and Flamant, C.: The importance of the diurnal cycle of Aerosol Optical Depth in West Africa, Geophys. Res. Lett., 40, 785-790, doi:10.1002/grl.50143, 2013.

Korontzi, S., McCarty, J., Loboda, T., Kumar, S., and Justice, C.: Global distribution of agricultural fires in croplands from 3 years of Moderate Resolution Imaging Spectroradiometer (MODIS) data, Global Biogeochem. Cy., 20, GB2021, doi:10.1029/2005GB002529, 2006.

Lawrence, M. G. and Lelieveld, J.: Atmospheric pollutant outflow from southern Asia: a review, Atmos. Chem. Phys., 10, 1101711096, doi:10.5194/acp-10-11017-2010, 2010.

Lee, J., Kim, J., Song, C. H., Kim, S. B., Chun, Y., and Sohn, B. J.: Characteristics of aerosol types from AERONET sunphotometer measurements, Atmos. Environ., 44, 3110-3117, doi:10.1016/j.atmosenv.2010.05.035, 2010.

Levy, R. C., Leptoukh, G. G., Kahn, R., Zubko, V., Gopalan, A., and Remer, L. A.: A Critical Look at Deriving Monthly Aerosol Optical Depth From Satellite Data, IEEE T. Geosci. Remote, 47, 2942-2956, doi:10.1109/TGRS.2009.2013842, 2009.

Levy, R. C., Remer, L. A., Kleidman, R. G., Mattoo, S., Ichoku, C., Kahn, R., and Eck, T. F.: Global evaluation of the Collection 5 MODIS dark-target aerosol products over land, Atmos. Chem. Phys., 10, 10399-10420, doi:10.5194/acp-10-10399-2010, 2010.

Li, Z., Zhao, X., Kahn, R., Mishchenko, M., Remer, L., Lee, K.-H., Wang, M., Laszlo, I., Nakajima, T., and Maring, H.: Uncertainties in satellite remote sensing of aerosols and impact on monitoring its longterm trend: a review and perspective, Ann. Geophys., 27, 2755-2770, doi:10.5194/angeo-27-2755-2009, 2009.

Lu, Z., Streets, D. G., Zhang, Q., Wang, S., Carmichael, G. R., Cheng, Y. F., Wei, C., Chin, M., Diehl, T., and Tan, Q.: Sulfur dioxide emissions in China and sulfur trends in East Asia since 2000, Atmos. Chem. Phys., 10, 6311-6331, doi:10.5194/acp-106311-2010, 2010.

Massie, T. S., Torres, O., and Smith, S. J.: Total ozone mapping spectrometer (TOMS) observations of increases in Asian aerosol 
in winter from 1979 to 2000, J. Geophys. Res., 109, D18211, doi:10.1029/2004JD004620, 2004.

Marmer, E., Langmann, B., Fagerli, H., and Vestreng, V.: Direct shortwave radiative forcing of sulphate aerosol over Europe from 1900 to 2000, J. Geophys. Res., 112, D23S17, doi:10.1029/2006JD008037, 2007.

Meehl, G. A., Covey, C., Delworth, T., Latif, M., McAvaney, B., Mitchell, J. F. B., Stouffer, R. J., and Taylor, K. E.: The WCRP CMIP3 multimodel dataset: A new era in climate change research, B. Am. Meteorol. Soc., 88, 1383-1394, doi:10.1175/BAMS-88-9-1383, 2007.

Mian Chin, Diehl, T., Tan, Q., Prospero, J. M., Kahn, R. A., Remer, L. A., Yu, H., Sayer, A. M., Bian, H., Geogdzhayev, I. V., Holben, B. N., Howell, S. G., Huebert, B. J., Hsu, N. C., Kim, D., Kucsera, T. L., Levy, R. C., Mishchenko, M. I., Pan, X., Quinn, P. K., Schuster, G. L., Streets, D. G., Strode, S. A., Torres, O., and Zhao, X.-P.: Multi-decadal variations of atmospheric aerosols from 1980 to 2009: sources and regional trends, Atmos. Chem. Phys. Discuss., 13, 19751-19835, doi:10.5194/acpd-1319751-2013, 2013

Mishchenko, M. and Geogdzhayev, I. V.: Satellite remote sensing reveals regional tropospheric aerosol trends, Opt. Express, 15, 7423-7438, doi:10.1364/OE.15.007423, 2007.

Mishchenko, M., Geogdzhayev, I. V., Rossow, W. B., Cairns, B., Carlson, B. E., Lacis, A. A., Liu, L., and Travis, L. D.: Longterm satellite record reveals likely recent aerosol trend, Science, 315, 1543, doi:10.1126/science.1136709, 2007.

Mu, M., Randerson, J. T., van der Werf, G. R., Giglio, L., Kasibhatla, P., Morton, D., Collatz, G. J., DeFries, R. S., Hyer, E. J., Prins, E. M., Griffith, D. W. T., Wunch, D., Toon, G. C., Sherlock, V., and Wennberg, P. O.: Daily and 3-hourly variability in global fire emissions and consequences for atmospheric model predictions of carbon monoxide, J. Geophys. Res., 116, D24303, doi:10.1029/2011JD016245, 2011.

Mudelsee, M.: Climate Time Series Analysis: Classical Statistical and Bootstrap Methods (Atmospheric and Oceanographic Sciences Library), Springer, Dordecht, Heildelberg, London, and New York, 74-77, ISBN:978-9048194810, 2010.

National Aeronautics and Space Administration (NASA): MODIS Web, available at: http://modis.gsfc.nasa.gov, last access: June 2014.

NOAA Earth System Research Laboratory: NCEP/NCAR Reanalysis Monthly Means and Other Derived Variables, available at: http://www.esrl.noaa.gov/psd/data/gridded/data.ncep. reanalysis.derived.html, last access: June 2014).

Ohara, T., Akimoto, H., Kurokawa, J., Horii, N., Yamaji, K., Yan, $\mathrm{X}$., and Hayasaka, T.: An Asian emission inventory of anthropogenic emission sources for the period 1980-2020, Atmos. Chem. Phys., 7, 4419-4444, doi:10.5194/acp-7-4419-2007, 2007

Pace, G., di Sarra, A., Meloni, D., Piacentino, S., and Chamard, P.: Aerosol optical properties at Lampedusa (Central Mediterranean). 1. Influence of transport and identification of different aerosol types, Atmos. Chem. Phys., 6, 697-713, doi:10.5194/acp-6-697-2006, 2006.

Pozzoli, L., Bey, I., Rast, S., Schultz, M. G., Stier, P., and Feichter, J.: Trace gas and aerosol interactions in the fully coupled model of aerosol-chemistry-climate ECHAM5HAMMOZ: 1. Model description and insights from the spring
2001 TRACE-P experiment, J. Geophys. Res., 113, D07308, doi:10.1029/2007JD009007, 2008.

Ramanathan, V., Li, F., Ramana, M. V., Praveen, P. S., Kim, D., Corrigan,, C. E., Nguyen, H., Stone, E. A., Schauer, J. J., Carmichael, G. R., Adhikary, B., and Yoon, S. C.: Atmospheric brown clouds: Hemispherical and regional variations in long-range transport, absorption, and radiative forcing, J. Geophys. Res., 112, D22S21, doi:10.1029/2006JD008124, 2007a.

Ramanathan, V., Ramana, M. V., Roberts, G., Kim, D., Corrigan, C., Chung, C., and Winker, D.: Warming trends in Asia amplified by brown cloud solar absorption, Nature Letters, 448, 575-578, doi:10.1038/nature06019, 2007b.

Remer, L. A., Gasso, S., Hegg, D. A., Kaufman, Y. J., and B. N. Holben: Urban/industrial aerosol: Ground-based sun/sky radiometer and airborne in situ measurements, J. Geophys. Res., 102, 16849-16859, doi:10.1029/96JD01932, 1997.

Remer, L. A., Kaufman, Y. J., Tanré, D., Mattoo, S., Chu, D. A., Martins, J. V., Li, R.-R., Ichoku, C., Levy, R. C., Kleidman, R. G., Eck, T. F., Vermote, E., and Holben, B. N.: The MODIS Aerosol Algorithm, Products, and Validation, J. Atmos. Sci., 62, 947-973, doi:10.1175/JAS3385.1, 2005.

Remer, L. A., Kleidman, R. G., Levy, R. C., Kaufman, Y. J., Tanré, D., Mattoo, S., Martins, J. V., Ichoku, C., Koren, I., Yu, H., and Holben, B. N.: Global aerosol climatology from the MODIS satellite sensors, J. Geophys. Res., 113, D14S07, doi:10.1029/2007JD009661, 2008.

Richter, A., Eyring, V., Burrows, J. P., Bovensmann, H., Lauer, A., Sierk, B., and Crutzen, P. J.: Satellite Measurements of $\mathrm{NO}_{2}$ from International Shipping Emissions, Geophys. Res. Lett., 31, L23110, doi:10.1029/2004GL020822, 2004.

Richter, A., Burrows, J. P., Nü $\beta$, H., Granier, C., and Niemeier, U.: Increase in tropospheric nitrogen dioxide over China observed from space, Nature Letters, 437, 129-132, doi:10.1038/nature04092, 2005.

Sabbah, I., Saeed, T., Al Jassar, H. K., and Rao, K. S.: Remote sensing of desert dust in Kuwait, J. Sci. Eng., 33, 101-117, 2006.

Sadrinasab, M. and Kämpf, J.: Three-dimensional flushing times of the Persian Gulf, Geophys. Res. Lett., 31, L24301, doi:10.1029/2004GL020425, 2004.

Schutgens, N. A. J., Nakata, M., and Nakajima, T.: Validation and empirical correction of MODIS AOT and AE over ocean, Atmos. Meas. Tech., 6, 2455-2475, doi:10.5194/amt-6-2455-2013, 2013.

Shi, Y., Zhang, J., Reid, J. S., Holben, B., Hyer, E. J., and Curtis, C.: An analysis of the collection 5 MODIS over-ocean aerosol optical depth product for its implication in aerosol assimilation, Atmos. Chem. Phys., 11, 557-565, doi:10.5194/acp-11-557-2011, 2011.

Smirnov, A., Holben, B. N., Eck, T. F., Slutsker, I., Chatenet, B., and Pinker, R. T.: Diurnal variability of aerosol optical depth observed at AERONET (Aerosol Robotic Network) sites, Geophys. Res. Lett., 29, 30-1-30-4, doi:10.1029/2002GL016305, 2002.

Smith, S. J., Pitcher, H., and Wigley, T. M. L.: Global and regional anthropogenic sulfur dioxide emissions, Global Planet. Change, 29, 99-119, doi:10.1016/S0921-8181(00)00057-6, 2001.

Smith, S. J., Andres, R., Conception, E., and Lurz, J.: Historical sulfur dioxide emissions 1850-2000: Methods and results, PNNL Res. Rep. 14537, Pac. Northwest Natl. Lab., Richland, Wash, 2003. 
Solomon, S., Qin, D., Manning, M., Chen, Z., Marquis, M., Averyt, K. B., Tignor, M., and Miller, H. L.: Climate Change 2007, The Physical Science Basis - Contribution of Working Group I to the Fourth Assessment Report of the Intergovernmental Panel on Climate Change (IPCC), Cambridge University Press, Cambridge, United Kingdom and New York, USA, ISBN:9780521705967, 2007.

Streets, D. G., Bond, T. C., Carmichael, G. R., Fernandes, S. D., Fu, Q., He, D., Klimont, Z., Nelson, S. M., Tsai, N. Y., Wang, M. Q., Woo, J.-H., and Yarber, K. F.: An inventory of gaseous and primary aerosol emissions in Asia in the year 2000, J. Geophys. Res., 108, 8809, doi:10.1029/2002JD003093, 2003.

Streets, D. G., Wu, Y., and Chin, M.: Two-decadal aerosol trends as a likely explanation of the global dimming/brightening transition, Geophys. Res. Lett., 33, L15806, doi:10.1029/2006GL026471, 2006.

Tafuro, A. M., Barnaba, F., De Tomasi, F., Perrone, M. R., and Gobbi, G. P.: Saharan dust particle properties over the central Mediterranean, Atmos. Res., 81, 67-93, doi:10.1016/j.atmosres.2005.11.008, 2006.

Taylor, K. E.: Summarizing multiple aspects of model performance in a single diagram, J. Geophys. Res., 106, 7183-7192, doi:10.1029/2000JD900719, 2001.

Thomas, G. E., Poulsen, C. A., Siddans, R., Sayer, A. M., Carboni, E., Marsh, S. H., Dean, S. M., Grainger, R. G., and Lawrence, B. N.: Validation of the GRAPE single view aerosol retrieval for ATSR-2 and insights into the long term global AOD trend over the ocean, Atmos. Chem. Phys., 10, 4849-4866, doi:10.5194/acp-10-4849-2010, 2010.

Torres, O., Bhartia, P. K., Herman, J. R., Ahmad, Z., and Gleason, J.: Derivation of aerosol properties from satellite measurements of backscattered ultraviolet radiation: Theoretical basis, J. Geophys. Res., 103, 17099-17110, doi:10.1029/98JD00900, 1998.

Torres, O., Bhartia, P. K., Herman, J. R., Sinyuk, A., and Holben, B.: A long term record of aerosol optical thickness from TOMS observations and comparison to AERONET measurements, J. Atmos. Sci., 59, 398-413, doi:10.1175/15200469(2002)059<0398:ALTROA>2.0.CO;2, 2002.

Veefkind, J. P., Boersma, K. F., Wang, J., Kurosu, T. P., Krotkov, N., Chance, K., and Levelt, P. F.: Global satellite analysis of the relation between aerosols and short-lived trace gases, Atmos. Chem. Phys., 11, 1255-1267, doi:10.5194/acp-11-1255-2011, 2011.

von Hoyningen-Huene, W., Freitag, M., and Burrows, J. P.: Retrieval of aerosol optical thickness over land surfaces from top-of-atmosphere radiance, J. Geophys. Res., 108, D94260, doi:10.1029/2001JD002018, 2003.

von Hoyningen-Huene, W., Kokhanovsky, A. A., Burrows, J. P., Bruniquel-Pinel, V., Regner, P., and Baret, F.: Simultaneous Determination of Aerosol- and Surface Characteristics from Top-ofAtmosphere Reflectance using MERIS on board of ENVISAT, J. Adv. Space Res., 37, 2172-2177, doi:10.1016/j.asr.2006.03.017, 2006.

von Hoyningen-Huene, W., Yoon, J., Vountas, M., Istomina, L. G., Rohen, G., Dinter, T., Kokhanovsky, A. A., and Burrows, J. P.: Retrieval of spectral aerosol optical thickness over land using ocean color sensors MERIS and SeaWiFS, Atmos. Meas. Tech., 4, 151-171, doi:10.5194/amt-4-151-2011, 2011.

Wallace, J. M., and Hobbs, P. V.: Atmospheric Chemistry, in: Atmospheric Science, Second Edition: An Introductory Survey, edited by: Dmowska, R., Hartmann, D., and Rossby, H. T., Elsevier, MA, USA, California, USA, and London, UK, 153-207, 2006.

Weatherhead, E. C., Reinsel, G. C., Tiao, G. C., Meng, X.-L., Choi, D., Cheang, W.-K., Keller, T., DeLuisi, J., Wuebbles, D. J., Kerr, J. B., Miller, A. J., Oltmans, S. J., and Frederick, J. E.: Factors affecting the detection of trends: Statistical considerations and applications to environmental data, J. Geophys. Res., 103, 1714917161, doi:10.1029/98JD00995, 1998.

Weatherhead, E. C., Stevermer, A. J., and Schwartz, B. E.: Detecting environmental changes and trends, Phys. Chem. Earth, 27, 399403, doi:10.1016/S1474-7065(02)00019-0, 2002.

Westerling, A. L., Hidalgo, H. G., Cayan, D. R., and Swetnam, T. W.: Warming and Earlier Spring Increase Western U.S. Forest Wildfire Activity, Science, 313, 940-943, doi:10.1126/science.1128834, 2006.

World Bank Group: The World Bank Data, http://data.worldbank. org/, last access: June 2014.

World Health Organization (WHO): Health topics, Air pollution, available at: http://www.who.int/topics/air_pollution/en/, last access: June 2014.

World Meteorological Organization (WMO): Systematic Observation Requirements for Satellite-based Products for Climate Supplemental details to the satellite-based component of the Implementation Plan for the Global Observing System for Climate in Support of the UNFCCC - 2011 Update, GCOS - 154, 1-127, 2011.

Xie, J. and Xia, X.: Long-term trend in aerosol optical depth from 1980 to 2001 in north China, Particuology, 6, 106-111, doi:10.1016/j.partic.2007.11.002, 2008.

Yoon, J. -M., Kim, J., Lee, J. H., Cho, H. K., Shon, B. J., and Ahn, M. H.: Retrieval of Aerosol Optical Depth over East Asia from a Geostationary Satellite, MTSAT-1R, J. Korean Meteor. Soc., 43, 133-142, 2007.

Yoon, J., von Hoyningen-Huene, W., Vountas, M., and Burrows, J. P.: Analysis of linear long-term trend of aerosol optical thickness derived from SeaWiFS using BAER over Europe and South China, Atmos. Chem. Phys., 11, 12149-12167, doi:10.5194/acp11-12149-2011, 2011.

Yoon, J., von Hoyningen-Huene, W., Kokhanovsky, A. A., Vountas, M., and Burrows, J. P.: Trend analysis of aerosol optical thickness and Ångström exponent derived from the global AERONET spectral observations, Atmos. Meas. Tech., 5, 12711299, doi:10.5194/amt-5-1271-2012, 2012.

Yu, H., Chin, M., Remer, L. A., Kleidman, R. G., Bellouin, N., Bian, H., and Diehl, T.: Variability of marine aerosol finemode fraction and estimates of anthropogenic aerosol component over cloud-free oceans from the Moderate Resolution Imaging Spectroradiometer (MODIS), J. Geophys. Res., 114, D10206, doi:10.1029/2008JD010648, 2009.

Zhang, J. and Reid, J. S.: MODIS aerosol product analysis for data assimilation: Assessment of over-ocean level 2 aerosol optical thickness retrievals, J. Geophys. Res., 111, D22207, doi:10.1029/2005JD006898, 2006.

Zhang, J. and Reid, J. S.: A decadal regional and global trend analysis of the aerosol optical depth using a data-assimilation grade over-water MODIS and Level 2 MISR aerosol products, Atmos. Chem. Phys., 10, 10949-10963, doi:10.5194/acp-1010949-2010, 2010. 
Zhang, X. Y., Gong, S. L., Zhao, T. L., Arimoto, R., Wang, T. Q., and Zhou, Z. J.: Sources of Asian dust and role of climate change versus desertification in Asian dust emission, Geophys. Res. Lett., 30, 2272, doi:10.1029/2003GL018206, 2003.

Zhao, T. X.-P., Laszlo, I., Guo, W., Heidinger, A., Cao, C., Jelenak, A., Tarpley, D., and Sullivan, J.: Study of long-term trend in aerosol optical thickness observed from operational AVHRR satellite instrument, J. Geophys. Res., 113, D07201, doi:10.1029/2007JD009061, 2008.
Zhao, T. X.-P., Chan, P. K., and Heidinger, A. K.: A global survey of the effect of cloud contamination on the aerosol optical thickness and its long-term trend derived from operational AVHRR satellite observations, J. Geophys. Res.-Atmos., 118, 2849-2857, doi:10.1002/jgrd.50278, 2013.

Zhou, Y., Brunner, D., Hueglin, C., Henne, S., and Staehelin, J.: Changes in OMI tropospheric $\mathrm{NO}_{2}$ columns over Europe from 2004 to 2009 and the influence of meteorological variability, Atmos. Environ., 46, 482-495, doi:10.1016/j.atmosenv.2011.09.024, 2012. 